\title{
Review \\ Small-Pore Zeolite Membranes: A Review of Gas Separation Applications and Membrane Preparation
}

\author{
Zishu Cao ${ }^{1}$, Ninad D. Anjikar ${ }^{2}$ and Shaowei Yang ${ }^{2, *}$ \\ 1 Department of Chemical and Environmental Engineering, University of Cincinnati, \\ Cincinnati, OH 45221, USA; caozu@ucmail.uc.edu \\ 2 Department of Chemical and Biomedical Engineering, Cleveland State University, \\ Cleveland, OH 44115, USA; n.anjikar@vikes.csuohio.edu \\ * Correspondence: s.yang4@csuohio.edu
}

check for updates

Citation: Cao, Z.; Anjikar, N.D.;

Yang, S. Small-Pore Zeolite

Membranes: A Review of Gas

Separation Applications and

Membrane Preparation. Separations

2022, 9, 47. https://doi.org/10.3390/

separations 9020047

Academic Editor: Victoria Samanidou

Received: 1 January 2022

Accepted: 29 January 2022

Published: 9 February 2022

Publisher's Note: MDPI stays neutral with regard to jurisdictional claims in published maps and institutional affiliations.

Copyright: () 2022 by the authors Licensee MDPI, Basel, Switzerland. This article is an open access article distributed under the terms and conditions of the Creative Commons Attribution (CC BY) license (https:/ / creativecommons.org/licenses/by/ $4.0 /)$.

\begin{abstract}
There have been significant advancements in small-pore zeolite membranes in recent years. With pore size closely related to many energy- or environment-related gas molecules, small-pore zeolite membranes have demonstrated great potential for the separation of some interested gas pairs, such as $\mathrm{CO}_{2} / \mathrm{CH}_{4}, \mathrm{CO}_{2} / \mathrm{N}_{2}$ and $\mathrm{N}_{2} / \mathrm{CH}_{4}$. Small-pore zeolite membranes share some characteristics but also have distinctive differences depending on their framework, structure and zeolite chemistry. Through this mini review, the separation performance of different types of zeolite membranes with respect to interested gas pairs will be compared. We aim to give readers an idea of membrane separation status. A few representative synthesis conditions are arbitrarily chosen and summarized, along with the corresponding separation performance. This review can be used as a quick reference with respect to the influence of synthesis conditions on membrane quality. At the end, some general findings and perspectives will be discussed.
\end{abstract}

Keywords: small-pore zeolite; zeolite membrane; gas separation; carbon capture

\section{Introduction}

Zeolites are crystalline microporous aluminosilicates formed by $\mathrm{TO}_{4}(\mathrm{~T}=\mathrm{Si}, \mathrm{Al}, \mathrm{B}$, $\mathrm{Ti}, \mathrm{P}$, etc.) tetrahedrons. Their uniform pore sizes are defined by their specific crystalline structures. Together with good chemical and thermal stability, they offer great potential as membrane materials to achieve highly selective separation of many interested separations, such as xylene isomers [1], butane isomers [2] and $\mathrm{CO}_{2} / \mathrm{CH}_{4}$ [3]. Zeolites are often referred to by their common names, such as ZSM-5, silicalite-1, SAPO-34 and NaA zeolites, that were given by initial inventors or based on their chemical compositions. To differentiate different types of zeolites by their crystal framework structure, a three-letter code is given for each zeolite structure by the International Zeolite Association (IZA). More information about the structures, pore size and example synthesis conditions can be found from IZA website or the Atlas of Zeolite Framework Types handbook [4]. Depending on the number of oxygen atoms (or T) forming the largest pore, zeolites can roughly be categorized as small-pore (8-membered), medium-pore (10), large-pore (12) and extra-large-pore (14 and larger). Since the initial conceptualization of zeolite membranes and first attempts to prepare zeolite membranes in the late 1980s [5,6], various types of zeolite have been made as membranes. There are a few good general reviews about zeolite membranes by Tavolaro, Caro, Lin, Khulbe and Tsapatsis [7-11].

Small-pore zeolites share certain characteristics in terms of their pore size and potential applications. However, slight structural or chemical differences can lead to drastic differences in separation performance and membrane preparation. A comparative review will give researchers a better overall picture of small-pore zeolite membranes. As of 2007, 59 small-pore zeolites were documented [4]. Some of the more thoroughly explored zeolites 
were summarized by Moliner et al. [12] Pore-structure information and membrane fabrication status of the most explored small-pore zeolites are summarized in Table 1. Only eight types of small-pore zeolite have been fabricated as zeolite membranes. The most explored are CHA, DDR and LTA zeolite membranes. For each, there are more than two dozen papers published. AEI zeolite membranes are also attracting significant research interest. There are fewer than five papers published about ANA-, ERI-, GIS- or RHO-type zeolite membranes. From their structures, it can be found that AEI, CHA, KFI and SAV have similar pore size and three-dimensional structures. AEI- and CHA-type zeolite membranes have been fabricated and demonstrated similar separation performance [13,14]. It is reasonable to hypothesize that KFI and SAV zeolite membranes, if prepared in nonionic forms, might have similar separation characteristics. LTA and SAS have a slightly larger pore size than CHA. Molecular sieving effects are expected to deviate from CHA membranes. This is in agreement with the $\mathrm{CO}_{2} / \mathrm{CH}_{4}$ separation-selectivity difference observed experimentally between the membranes $[15,16]$. On the other hand, AFX and RHO zeolites have a slightly smaller pore size and are expected to have a better molecular sieving effect for gas pairs such as $\mathrm{O}_{2} / \mathrm{N}_{2}$ and $\mathrm{N}_{2} / \mathrm{CH}_{4}$. Most studied zeolites have circular or slightly oval-shape pores. The slightly oval-shaped pore openings of DDR do not differentiate its separation characteristics much from those of CHA zeolite with circular pores. However, zeolites with large-ratio oval-shape pores, such as GIS, NSI and RWR, are expected to have quite different steric effects for different molecules. These membranes, particularly their nonionic forms, are interesting for gas separation exploration for new discoveries.

Table 1. Most explored small-pore zeolites [12], their pore architectures and sizes for corresponding pure silica forms [4] and membrane fabrication status.

\begin{tabular}{ccccc}
\hline IZA Code & Zeolite Names & Pore Architecture & Pore Size, A & Membranes \\
\hline AEI & SSZ-39, AlPO-18, SIZ-8 & $8 \times 8 \times 8$ & $3.8 \times 3.8$ & Y \\
AFX & SAPO-56, SSZ-16 & $8 \times 8 \times 8$ & $3.4 \times 3.6$ & $\mathrm{~N}$ \\
ANA & Analcime, AlPO-24 & $8 \times 8 \times 8$ & $1.6 \times 4.2$ & Y \\
CHA & SSZ-13, SAPO-34 & $8 \times 8 \times 8$ & $3.8 \times 3.8$ & Y \\
DDR & ZSM-58, Deca-dodecasil 3R & $8 \times 8$ & $3.6 \times 4.4$ & Y \\
ERI & UZM-12, AlPO-17 & $8 \times 8 \times 8$ & $3.6 \times 5.1$ & Y \\
GIS & Gismondine, Zeolite P & $8 \times 8 \times 8$ & $3.1 \times 4.5,2.8 \times 4.8$ & Y \\
IHW & ITQ-32 & $8 \times 8$ & $3.5 \times 4.3$ & $\mathrm{~N}$ \\
ITE & ITQ-3 & $8 \times 8$ & $3.8 \times 4.3,2.7 \times 5.8$ & $\mathrm{~N}$ \\
ITW & ITQ-12 & $8 \times 8$ & $2.4 \times 5.4,3.9 \times 4.2$ & $\mathrm{~N}$ \\
KFI & ZK-5 & $8 \times 8 \times 8$ & $3.9 \times 3.9$ & $\mathrm{~N}$ \\
LEV & Levyne, SAPO-35 & $8 \times 8$ & $3.6 \times 4.8$ & $\mathrm{~N}$ \\
LTA & Linde Type A, ITQ-29 & $8 \times 8 \times 8$ & $4.1 \times 4.1$ & $\mathrm{Y}$ \\
NSI & Nu-6(2) & $8 \times 8$ & $2.6 \times 4.5,2.4 \times 4.8$ & $\mathrm{~N}$ \\
RHO & RHO & $8 \times 8 \times 8$ & $3.6 \times 3.6$ & $\mathrm{Y}$ \\
RTE & RUB-3 & $8 \times 8$ & $3.8 \times 4.1,2.5 \times 5.6$ & $\mathrm{~N}$ \\
RTH & RUB-13, SSZ-50 & $8 \times 8$ & $2.8 \times 5.0$ & $\mathrm{~N}$ \\
RWR & RUB-24 & $8 \times 8 \times 8$ & $3.8 \times 3.8,3.9 \times 3.9$ & $\mathrm{~N}$ \\
SAS & STA-6, SSZ-73 & $8 \times 8$ & $3.6 \times 4.4,3.2 \times 3.2$ & $\mathrm{~N}$ \\
SAV & STA-7 & UZM-5 & $\mathrm{N}$ & \\
UFI & & & &
\end{tabular}

The purpose of this review is to give an overview of small-pore zeolite membranes for gas separation applications. For each type of zeolite membrane, a thorough discussion about synthesis conditions will also be given. Small-pore zeolite membranes have found many non-gaseous applications, such as desalination and pervaporative dehydration of solvents [17-19]. These applications are beyond the scope of this review. Zeolites are also commonly used as fillers in mixed-matrix membranes (MMMs) or composite membranes. A review of zeolite filler in MMMs was written by Bastani and colleagues [20]. The discussion in this review is limited to pure zeolite membranes, i.e., continuous zeolite films as the effective membrane materials. A thorough discussion of SAPO-34 zeolite membranes was recently conducted by $\mathrm{Xu}$ et al. [21], and their article serves as a good reference for SAPO-34 zeolite membrane synthesis, which is not covered in this review. 
Zeolite membrane synthesis could roughly be categorized according to three methods: in situ synthesis, secondary growth and dry gel conversion. For a typical synthesis, the precursor gel is prepared by mixing $\mathrm{Si}$ source, Al source, an organic-structure-directing agent (OSDA; if not used, it is denoted as OSDA-free synthesis), water and/or mineralizing agent, i.e., $\mathrm{F}^{-}$or $\mathrm{OH}^{-}$. No seed crystals (same-type zeolite) are used for in situ synthesis; the precursor gel is directly poured into a container with porous substrate inside. The vessel is then sealed in an autoclave and put in a preheated oven for hydrothermal synthesis. Nucleation happens on the substrate surface, and a continuous film forms as crystallization continues. When synthesis ends, the membrane is rinsed with water and dried. A membrane-activation step is required to remove the OSDA inside the zeolite. The activation is typically achieved by calcination in air at temperatures above $673 \mathrm{~K}$. Ozone in lower temperatures and UV irradiation at near-ambient conditions have also been successfully utilized to activate zeolite membranes [22,23]. The major advantage of the in situ method is its simplicity. For secondary growth, seed crystals are first coated on a substrate surface to promote nucleation and crystallization. Other operations are essentially the same. Typically, shorter synthesis duration is required for secondary growth compared to the in situ method. The nucleation rate for the in situ method strongly depends on substrate surface properties, such as surface chemistry, pore size and surface evenness. It is challenging to form a continuous film when there are not enough nuclei on the substrate surface. Secondary growth is less affected by substrate properties and is generally more applicable. The dry gel conversion method is also referred as the vapor-phase transformation method. It works by coating the substrate with precursor gel, followed by converting the gel to crystals under a steam and/or OSDA atmosphere. The dry gel conversion method often results in moderate membrane quality and is less commonly used, despite the advantage of much less chemical consumption.

A few parameters are commonly used to describe membrane performance. The speed at which molecules permeate the membrane is described by permeance $\left(P_{m}\right)$, which is the flux normalized by the driving force, i.e., (partial) pressure difference. Ideal selectivity $\left(\alpha_{i / j}^{o}\right)$ is the ratio of permeances for two different components, $i$ and $j$, measured independently with pure feed. The separation selectivity from a mixture separation test, typically by the Wicke-Kallenbach method, is called separation factor $\left(\alpha_{i / j}\right)$. Permeance strongly depends on how thick the effective membrane layer is. To fairly compare different membrane materials, permeability is determined by multiplying permeance by membrane thickness. Permeability is a material property and more commonly used for polymer membranes.

$$
\begin{gathered}
P_{m, i}=\frac{Q}{A_{m} \cdot t \cdot \Delta P_{i}} \\
\alpha_{i / j}^{o}=P_{m, i}^{o} / P_{m, j}^{o} \\
\alpha_{i / j}=\frac{y_{i} / y_{j}}{x_{i} / x_{j}} \\
P_{b, i}=P_{m, i} \cdot \delta
\end{gathered}
$$

where $Q$ is the moles of component $i$ permeated through the membrane over a time period of $t(s) ; \Delta P_{i}$ is the partial pressure difference (i.e., $\Delta P_{i}=P_{i, f}-P_{i, p}$, where $P_{i, f}$ and $P_{i, p}$ are the partial pressures of gas component $i$ on the feed and permeate sides, respectively); $P_{m, i}^{o}$ and $P_{m, j}^{o}$ are pure gas permeance of gas $i$ and $j$, respectively; $x$ and $y$ are molar fractions of the feed and permeate gas, respectively; $\delta$ is the membrane thickness; and $P_{b, i}$ is the membrane-material permeability for component $i$.

\section{Membrane Separation Applications}

2.1. $\mathrm{CO}_{2} / \mathrm{CH}_{4}$

$\mathrm{CO}_{2} / \mathrm{CH}_{4}$ separation is the most explored application for small-pore zeolite membranes. Natural gas should meet the maximum allowed $\mathrm{CO}_{2}$ concentration requirement to 
mitigate corrosion concern before it is allowed in pipelines for transportation. For some natural gas sources, excess $\mathrm{CO}_{2}$ has to be removed. $\mathrm{CO}_{2}$ and $\mathrm{CH}_{4}$ have a kinetic size of 0.33 and $0.38 \mathrm{~nm}$, respectively. Small-pore zeolite membranes, such as CHA, DDR and AEI, have pore sizes of about $0.38 \mathrm{~nm}$, which is approaching the size of $\mathrm{CH}_{4}$ and could potentially achieve great selectivity through the molecular sieving effect. The separation performance of different types of small-pore zeolite membranes is summarized and plotted in Figure 1. Polymer membranes are more mature membrane materials and have found more industrial applications. Polymer membranes typically have a trade-off between permeability and selectivity. The permeability vs. selectivity for different gas pairs was first summarized in 1991 and updated in 2008 by Robeson [24,25]. The state-of-the-art performance was named the Robeson upper bound. For a Robeson plot, selectivity is plotted vs. permeability instead of permeance. However, for zeolite membranes, the membrane-preparation method and substrate porosity, among other factors, could affect membrane permeance instead of just membrane thickness. Therefore, permeances are often compared instead of permeability to determine state-of-the-art membrane fabrication. The 2008 Robeson upper bound for polymers is adopted and replotted in Figure 1 by assuming a membrane thickness of $1 \mu \mathrm{m}$, which was also assumed by Koros and Zhang when comparing inorganic membranes with polymer membranes [26]. Small-pore zeolite membranes performed well above the 2008 Robeson upper bound for $\mathrm{CO}_{2} / \mathrm{CH}_{4}$ separation. Particularly for a high selectivity range, the permeance is up to two to three orders of magnitude higher than that of conventional polymers. It should be noted that there is continuous development of new polymer membrane materials, particularly thermally rearranged (TR) polymers, polymers with intrinsic microporosity (PIMs) and perfluoropolymers [27-29]. The polymer upper bound has been pushed forward over the past decade but has not been updated. For $\mathrm{CO}_{2} / \mathrm{CH}_{4}$ selectivity over 100 , zeolite membranes still outperform polymers and are attractive for industrial applications.

Among the zeolite membranes, high-silica $\mathrm{CHA}$ (denoted as $\mathrm{CHA}(\mathrm{Si})$, also called SSZ-13) and SAPO-34 zeolite membranes have shown the highest $\mathrm{CO}_{2}$ permeance and $\mathrm{CO}_{2} / \mathrm{CH}_{4}$ selectivity. DDR zeolite membranes have shown excellent $\mathrm{CO}_{2} / \mathrm{CH}_{4}$ selectivity but relatively lower $\mathrm{CO}_{2}$ permeance. This could be explained by the fact that $\mathrm{CHA}$ zeolite has three-dimensional zeolitic channels, while DDR zeolite only has two-dimensional zeolitic channels. The less effective channels limit the membrane permeability of DDR zeolites. AEI is another zeolite membrane with high potential, as demonstrated by good separation selectivity and permeance with AlPO-18 (aluminophosphate form of AEI) membranes $[14,30]$. With good control of membrane quality and suppressed crystal growth inside substrate pores, AEI membranes are expected to achieve a separation performance similar to that of SSZ-13. Another important consideration is the influence from third component on membrane performance. Water vapor is the most commonly studied; $\mathrm{CO}_{2}$ permeance for high-silica CHA and AlPO-18 membranes is less affected by water vapor compared to SAPO-34 membranes because of fewer cations to balance the charge and thus less polarity [31-34]. At low temperatures, SAPO-34 zeolite membranes could lose up to $99 \%$ of $\mathrm{CO}_{2}$ permeance for humid feed compared to dry feed [34]. At elevated temperatures and feed pressure, the influence of water vapor is less significant due to weaker water adsorption [35].

\section{2. $\mathrm{CO}_{2} / \mathrm{N}_{2}$}

Carbon capture from flue gas (mainly $\mathrm{CO}_{2} / \mathrm{N}_{2}$ separation) is important to address the increasing climate concern. The kinetic diameter of $\mathrm{CO}_{2}(0.33 \mathrm{~nm})$ is slightly smaller than that of $\mathrm{N}_{2}(0.364 \mathrm{~nm})$, and $\mathrm{CO}_{2}$ adsorption uptake is higher than $\mathrm{N}_{2}$ adsorption uptake in zeolites. That makes small-pore zeolite membranes potential candidates for $\mathrm{CO}_{2} / \mathrm{N}_{2}$ separation. As shown in Figure 2, only a few membranes outperformed the 2008 Robeson upper bound. SAPO-34 zeolite membrane demonstrated higher selectivity for $\mathrm{CO}_{2} / \mathrm{N}_{2}$ than other membranes. Chew et al. reported a SAPO-34 membrane with a $\mathrm{CO}_{2}$ permeance of $1.75 \times 10^{-6} \mathrm{~mol} \cdot \mathrm{m}^{-2} \cdot \mathrm{Pa}^{-1} \cdot \mathrm{s}^{-1}$ and a $\mathrm{CO}_{2} / \mathrm{N}_{2}$ separation factor of $78 \mathrm{for}$ 
the separation of $5 \% \mathrm{CO}_{2}$ in a $\mathrm{CO}_{2} / \mathrm{N}_{2}$ mixture at $303 \mathrm{~K}$ [107]. Makertihartha et al. also reported a SAPO-34 membrane with a $\mathrm{CO}_{2}$ permeance of $2.0 \times 10^{-6} \mathrm{~mol} \cdot \mathrm{m}^{-2} \cdot \mathrm{Pa}^{-1} \cdot \mathrm{s}^{-1}$ and a $\mathrm{CO}_{2} / \mathrm{N}_{2}$ ideal selectivity of 53 at $300 \mathrm{~K}$ [108]. AEI membranes reported by Wang et al. and a DDR zeolite membrane reported by Hayakawa et al. also demonstrated good $\mathrm{CO}_{2} / \mathrm{N}_{2}$ selectivities of 45 and 44, respectively [14,87]. CHA zeolite membranes demonstrated slightly lower $\mathrm{CO}_{2} / \mathrm{N}_{2}$ selectivity despite high $\mathrm{CO}_{2}$ permeance. There was no $\mathrm{CO}_{2} / \mathrm{N}_{2}$ separation-performance report for the most permeable high-quality SSZ-13 membranes from $\mathrm{Yu}$ and coworkers [3]. These membranes are expected to have the highest $\mathrm{CO}_{2}$ permeance and moderate-to-good $\mathrm{CO}_{2} / \mathrm{N}_{2}$ selectivity. Overall, it is hard for small-pore zeolite membranes to compete with polymer membranes for $\mathrm{CO}_{2} / \mathrm{N}_{2}$ separation unless their selectivity can be significantly improved without sacrificing membrane permeance.

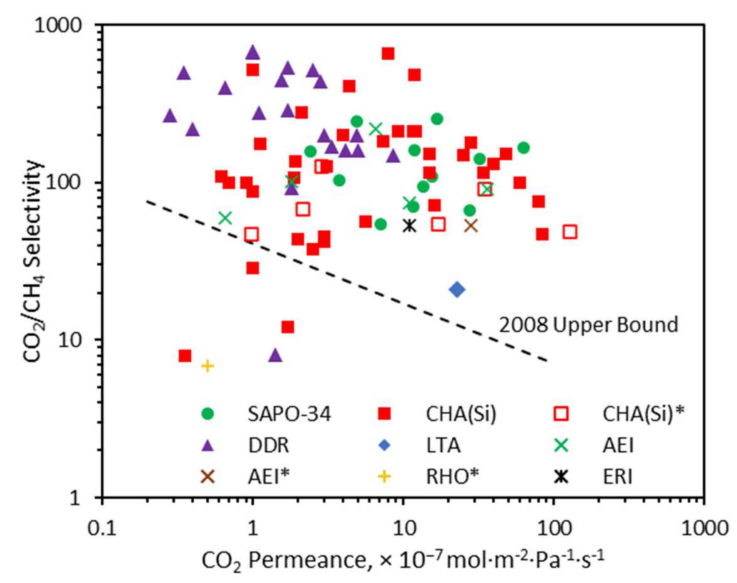

Figure 1. $\mathrm{CO}_{2} / \mathrm{CH}_{4}$ separation performance for different types of small-pore zeolite membranes $[3,13-15,22,23,30-33,36-106]$. * denotes results from pure gas permeation tests. The 2008 polymermembrane upper bound was replotted by assuming $1 \mu \mathrm{m}$ membrane thickness [25].

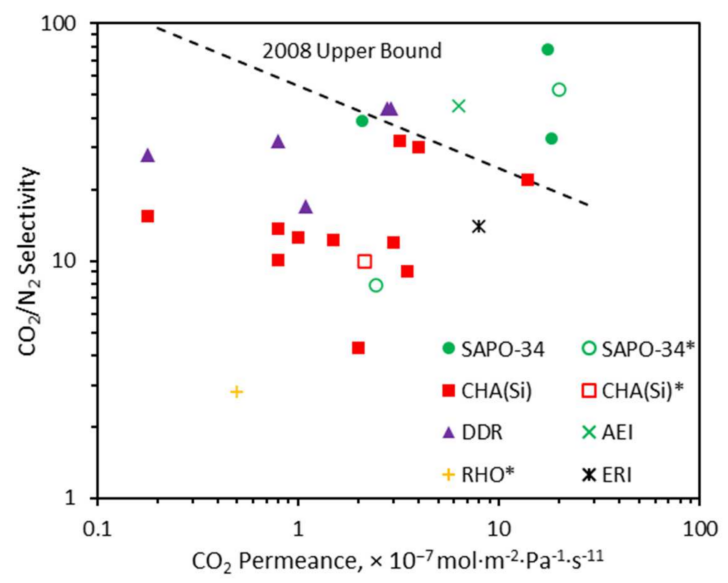

Figure 2. $\mathrm{CO}_{2} / \mathrm{N}_{2}$ separation performance for different types of small-pore zeolite membranes $[14,15,47,51,55,59,61,63,68,69,76,77,81,86,87,99,105-112]$. * denotes results from pure gas permeation tests. The 2008 polymer membrane upper bound was replotted by assuming $1 \mu \mathrm{m}$ membrane thickness [25].

\section{3. $\mathrm{H}_{2} / \mathrm{CO}_{2}$}

Precombustion $\mathrm{CO}_{2}$ capture is critical to mitigate $\mathrm{CO}_{2}$ emissions to address climate concerns [113,114]. In this process, fossil fuel or biomass is gasified to produce syngas comprising mainly $\mathrm{H}_{2}$ and $\mathrm{CO}$. The $\mathrm{CO}$ in syngas is then converted to $\mathrm{CO}_{2}$ through a water-gas shift reaction, producing $~ 55 \% \mathrm{H}_{2}$ and $\sim 40 \% \mathrm{CO}_{2} \cdot \mathrm{H}_{2} / \mathrm{CO}_{2}$ separation is crucial to produce pure $\mathrm{H}_{2}$ for turbines or ammonia plants and pure $\mathrm{CO}_{2}$ for utilization or sequestration. Kinetic sizes of both $\mathrm{H}_{2}$ and $\mathrm{CO}_{2}$ are appreciably smaller than the pore sizes of small-pore zeolites, i.e., CHA, DDR and LTA, studied for membrane separation. 
Moreover, $\mathrm{CO}_{2}$ adsorption uptake in zeolites is much higher than $\mathrm{H}_{2}$ adsorption uptake. This makes it very challenging to achieve highly $\mathrm{H}_{2}$-selective zeolite membranes. For ionic zeolites, the effective pore openings are changed with the cation gated zeolitic channels. Therefore, ionic zeolite membranes might perform quite differently from their non-ionic counterparts. The $\mathrm{H}_{2} / \mathrm{CO}_{2}$ separation performance of small-pore zeolite membranes is plotted in Figure 3. The most attractive separation performance was reported by Sen et al. for an $\mathrm{NaA}$ (LTA structure) zeolite membrane [101]. The membrane had thickness of $15 \mu \mathrm{m}$ and was prepared by an OSDA-free method on a clay- $\mathrm{Al}_{2} \mathrm{O}_{3}$ tube. It demonstrated an $\mathrm{H}_{2}$ permeance of $2.3 \times 10^{-6} \mathrm{~mol} \cdot \mathrm{m}^{-2} \cdot \mathrm{Pa}^{-1} \cdot \mathrm{s}^{-1}$ and an $\mathrm{H}_{2} / \mathrm{CO}_{2}$ separation factor of 16.2 at $303 \mathrm{~K}$. This performance is well above the 2008 Robeson upper bound. The other two LTA zeolite membranes that demonstrated relatively high $\mathrm{H}_{2} / \mathrm{CO}_{2}$ selectivity (12.5 and 7.4) are also $\mathrm{NaA}$ zeolite membranes prepared by OSDA-free synthesis, as reported by Huang et al. $[115,116]$. The highest $\mathrm{H}_{2} / \mathrm{CO}_{2}$ selectivity was reported by Zheng and Guliants for a DDR zeolite membrane [117]. The DDR membrane was defective after calcination. The membrane was repaired by chemical vapor deposition (CVD) with silica for six days at $823 \mathrm{~K}$. The high $\mathrm{H}_{2} / \mathrm{CO}_{2}$ selectivity, which was not observed by other researchers for DDR zeolite membranes [118,119], might be caused by a continuous amorphous silica film acting as an effective membrane for $\mathrm{H}_{2} / \mathrm{CO}_{2}$ separation.

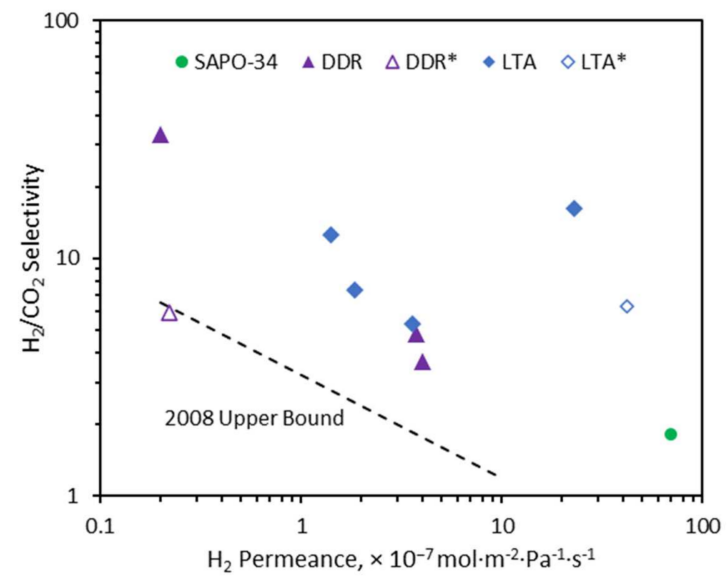

Figure 3. $\mathrm{H}_{2} / \mathrm{CO}_{2}$ separation performance for different types of small-pore zeolite membranes [101,115-123] * denotes results from pure gas permeation tests. The 2008 polymer membrane upper bound was replotted by assuming $1 \mu \mathrm{m}$ membrane thickness [25].

Another option to separate $\mathrm{H}_{2} / \mathrm{CO}_{2}$ is $\mathrm{CO}_{2}$-selective membranes. MFI (medium-pore zeolite, with a pore size $\sim 0.55 \mathrm{~nm}$ ) zeolite membranes have been extensively explored for $\mathrm{CO}_{2} / \mathrm{H}_{2}$ separation. In a recent work from $\mathrm{Yu}$ and Hedlund, an ultrathin MFI zeolite membrane demonstrated a $\mathrm{CO}_{2}$ permeance of $1 \times 10^{-5} \mathrm{~mol} \cdot \mathrm{m}^{-2} \cdot \mathrm{Pa}^{-1} \cdot \mathrm{s}^{-1}$ and a $\mathrm{CO}_{2} / \mathrm{H}_{2}$ separation factor of 45 at $288 \mathrm{~K}$ and 10 bar feed pressure [124]. The high selectivity is a result of competitive adsorption, and most zeolitic channels occupied by $\mathrm{CO}_{2}$, limiting $\mathrm{H}_{2}$ permeation. Temperature plays an important role in membrane selectivity. The $\mathrm{CO}_{2} / \mathrm{H}_{2}$ separation factor decreased to 13 when temperature increased from 288 to $316 \mathrm{~K}$. Smallpore zeolite could have a similar effect because of much stronger $\mathrm{CO}_{2}$ adsorption than $\mathrm{H}_{2}$. Liu et al. demonstrated an ultrahigh $\mathrm{CO}_{2} / \mathrm{H}_{2}$ selectivity of 161 with a $\mathrm{CO}_{2}$ permeance of $6.3 \times 10^{-7} \mathrm{~mol} \cdot \mathrm{m}^{-2} \cdot \mathrm{Pa}^{-1} \cdot \mathrm{s}^{-1}$ at $243 \mathrm{~K}$ and a pressure drop of $0.2 \mathrm{MPa}$ [125]. At $298 \mathrm{~K}$ and a pressure drop of $2.0 \mathrm{MPa}$, the $\mathrm{CO}_{2} / \mathrm{H}_{2}$ selectivity and $\mathrm{CO}_{2}$ permeance were 17.4 and $4.2 \times 10^{-7} \mathrm{~mol} \cdot \mathrm{m}^{-2} \cdot \mathrm{Pa}^{-1} \cdot \mathrm{s}^{-1}$, respectively. Zito et al. also demonstrated the good $\mathrm{CO}_{2} / \mathrm{H}_{2}$ selectivity of 17 with DDR zeolite membranes, although the $\mathrm{CO}_{2}$ permeance was relatively lower [112]. So far, small-pore zeolite membranes have demonstrated attractive separation performance for $\mathrm{CO}_{2} / \mathrm{H}_{2}$ separation. However, it is challenging to outperform MFI zeolite membranes. 


\section{4. $\mathrm{H}_{2}$ Separation from Hydrocarbons}

$\mathrm{H}_{2}$ is considered a clean fuel and an important energy resource to sustain growing energy demands [126]. A huge amount of $\mathrm{H}_{2}$ is generated as a byproduct in industrial processes, such as dehydrogenation reactions [127] and coal coking [128]. Coke oven gas (COG) from the coking process contains primary $\mathrm{H}_{2}$ and $\mathrm{CH}_{4}$, with a small amount of $\mathrm{CO}$, $\mathrm{CO}_{2}, \mathrm{~N}_{2}, \mathrm{H}_{2} \mathrm{O}, \mathrm{H}_{2} \mathrm{~S}$ and hydrocarbons. $\mathrm{H}_{2}$ is also produced during the dehydrogenation reaction in the production of ethylene and propylene. $\mathrm{H}_{2}$ separation from hydrocarbons is an important route for $\mathrm{H}_{2}$ production. Small-pore zeolite has pore size much larger than that of $\mathrm{H}_{2}$ but close to or slightly smaller than that of $\mathrm{CH}_{4}, \mathrm{C}_{2} \mathrm{H}_{6}, \mathrm{C}_{3} \mathrm{H}_{8}$. etc., which makes them attractive candidates to achieve highly selective separation through a molecular sieving effect. $\mathrm{H}_{2} / \mathrm{CH}_{4}$ separation performance for small-pore zeolite membranes is summarized in Figure 4. $\mathrm{CH}_{4}, \mathrm{C}_{2} \mathrm{H}_{6}$ and even $\mathrm{C}_{3} \mathrm{H}_{8}$ are not totally size-excluded from the zeolitic pores for DDR, CHA and LTA zeolites. For zeolite membranes with $\mathrm{H}_{2} / \mathrm{C}_{3} \mathrm{H}_{8}$ or $\mathrm{H}_{2} / \mathrm{i}-\mathrm{C}_{4} \mathrm{H}_{10}$ selectivity over 10,000 (i.e., an extremely low number of defects), $\mathrm{H}_{2} / \mathrm{CH}_{4}$ selectivity is about 100 or lower at room temperature, which is limited by the $\mathrm{H}_{2} / \mathrm{CH}_{4}$ permeability ratio in those materials. Dong et al. achieved an $\mathrm{H}_{2} / \mathrm{CH}_{4}$ separation factor of 263 at $473 \mathrm{~K}$ with a molecular layer deposition (MLD)-modified SSZ-13 zeolite membrane [129]. However, the membrane only had moderate $\mathrm{H}_{2}$ permeance. Attractive separation performance was also reported for high-silica CHA, SAPO-34 and DDR zeolite membranes [97,128,130]. Only reasonably good $\mathrm{H}_{2} / \mathrm{CH}_{4}$ separation performance was reported by pure gas measurements, as opposed to a mixture separation, for LTA-type zeolite membranes [123]. Overall, smallpore zeolite does not outperform the 2008 Robeson upper bound by much. With recent developments in polymer membranes, it is challenging for those studied small-pore zeolite membranes to be economically advantageous in comparison to polymer membranes.

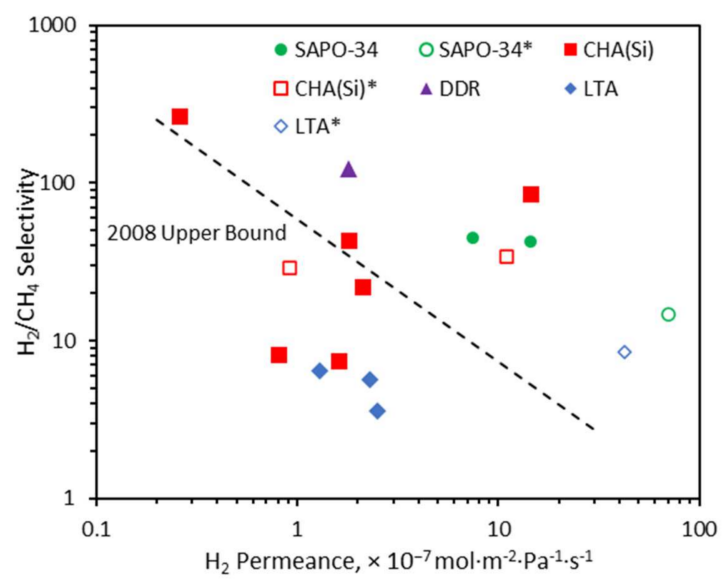

Figure 4. $\mathrm{H}_{2} / \mathrm{CH}_{4}$ separation performance for different types of small-pore zeolite membranes $[15,43$, $56,58,79,81,96,116,120,122,123,129-132]$. * denotes results from pure gas permeation tests. The 2008 polymer membrane upper bound was replotted by assuming $1 \mu \mathrm{m}$ membrane thickness [25].

Good $\mathrm{H}_{2} / \mathrm{C}_{3} \mathrm{H}_{8}$ and $\mathrm{H}_{2} / \mathrm{C}_{3} \mathrm{H}_{6}$ separation performances were demonstrated by Huang et al. with nonionic LTA-type zeolite membranes [16,132]. The hydrophobic ITQ-29 (with Si and $\mathrm{Ga}$ ) zeolite membrane demonstrated an $\mathrm{H}_{2} / \mathrm{C}_{3} \mathrm{H}_{8}$ separation factor of 127 and an $\mathrm{H}_{2}$ permeance of $3.64 \times 10^{-7} \mathrm{~mol} \cdot \mathrm{m}^{-2} \cdot \mathrm{Pa}^{-1} \cdot \mathrm{s}^{-1}$ at $573 \mathrm{~K}$ and $1 \mathrm{bar}$ feed pressure. Through silver exchange, they increased the $\mathrm{H}_{2} / \mathrm{C}_{3} \mathrm{H}_{8}$ separation factor from 19.4 for an $\mathrm{NaA}$ zeolite membrane to 120.8. Our high-silica CHA zeolite membrane also demonstrated an $\mathrm{H}_{2} / \mathrm{C}_{3} \mathrm{H}_{8}$ ideal selectivity of 260 at $295 \mathrm{~K}$ [23]. For the $\mathrm{H}_{2} / \mathrm{C}_{3} \mathrm{H}_{6} / \mathrm{C}_{3} \mathrm{H}_{8}$ ternary mixture separation test, $\mathrm{H}_{2}$ permeance $\left(5.5 \times 10^{-10} \mathrm{~mol} \cdot \mathrm{m}^{-2} \cdot \mathrm{Pa}^{-1} \cdot \mathrm{s}^{-1}\right)$ was much lower than pure the $\mathrm{H}_{2}$ permeance of $3.4 \times 10^{-8} \mathrm{~mol} \cdot \mathrm{m}^{-2} \cdot \mathrm{Pa}^{-1} \cdot \mathrm{s}^{-1}$ at $295 \mathrm{~K}$. This was caused by the strong adsorption of $\mathrm{C}_{3} \mathrm{H}_{6}$ and $\mathrm{C}_{3} \mathrm{H}_{8}$, which blocked the permeation of faster $\mathrm{H}_{2}$ molecules. However, $\mathrm{H}_{2} / \mathrm{C}_{3} \mathrm{H}_{8}$ permeance increased rapidly with temperature as less zeolitic channels were occupied by C3s. $\mathrm{H}_{2} / \mathrm{C}_{3} \mathrm{H}_{8}$ separation factor increased from 21 to 171 when temperature increased 
from 294 to $413 \mathrm{~K}$. Generally, higher operating temperatures might help $\mathrm{H}_{2} /$ hydrocarbon separation selectivity by weakening the competitive adsorption effect.

\section{5. $\mathrm{N}_{2} / \mathrm{CH}_{4}$}

Natural gas contains varying amounts of impurities depending on the resources. According to U.S. natural gas pipeline specifications, inert gases, such as $\mathrm{N}_{2}$, should have a concentration of less than $4 \%$ [133]. It is necessary to develop more energy-efficient separation technology for impurity removal. $\mathrm{N}_{2}$ and $\mathrm{CH}_{4}$ have similar kinetic diameters, i.e., $0.364 \mathrm{~nm}$ for $\mathrm{N}_{2}$ and $0.38 \mathrm{~nm}$ for $\mathrm{CH}_{4}$. Both $\mathrm{N}_{2}$ and $\mathrm{CH}_{4}$ are classified as weak adsorbates [73]. These properties make it very challenging to separate them. This is also evidenced by the relatively low-performing 2008 Robeson upper bound, as shown in Figure 5. Small-pore zeolite membranes, such as CHA, DDR and AEI, have poreopening approaching the size of $\mathrm{CH}_{4}$ and could potentially achieve great selectivity for the gas pair. CHA-type (SSZ-13 and SAPO = 34) and AEI-type (AlPO-18) demonstrated an $\mathrm{N}_{2} / \mathrm{CH}_{4}$ selectivity around 10 with good $\mathrm{N}_{2}$ permeance, which is well above the 2008 Robeson upper bound for polymer membranes. The best separation performance was from an SSZ-13 zeolite membrane reported by Li et al. [134]. The membrane had an $\mathrm{N}_{2}$ permeance of $8.5 \times 10^{-7} \mathrm{~mol} \cdot \mathrm{m}^{-2} \cdot \mathrm{Pa}^{-1} \cdot \mathrm{s}^{-1}$ and an $\mathrm{N}_{2} / \mathrm{CH}_{4}$ separation of 13.5 at $298 \mathrm{~K}$ and $0.303 \mathrm{MPa}$ feed pressure. Impressive separation performance was also achieved by SAPO-34 membranes $[135,136]$. Overall, zeolite membranes are promising candidates to achieve excellent separation performance for $\mathrm{N}_{2} / \mathrm{CH}_{4}$.

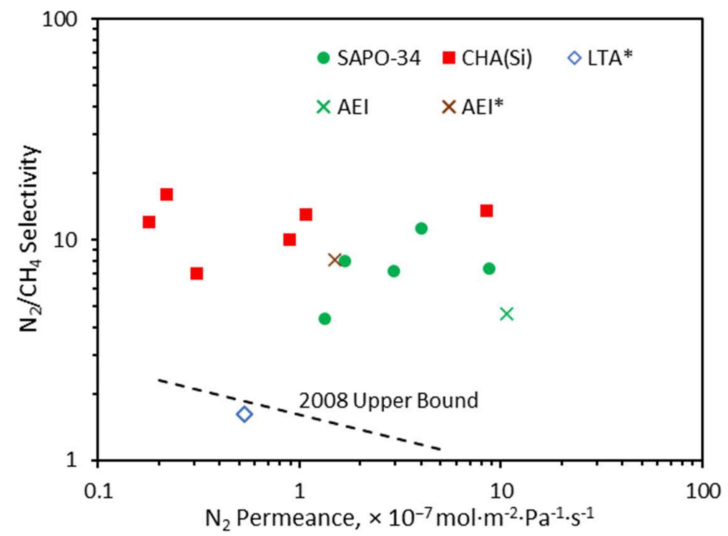

Figure 5. $\mathrm{N}_{2} / \mathrm{CH}_{4}$ separation performance for different types of small-pore zeolite membranes [15,62, $63,65,73,104,134-141]$. * denotes results from pure gas permeation tests. The 2008 polymer membrane upper bound was replotted by assuming $1 \mu \mathrm{m}$ membrane thickness [25].

\subsection{Other Separations}

Other explored gas separation applications include $\mathrm{O}_{2} / \mathrm{N}_{2}, \mathrm{Kr} / \mathrm{Xe}$, and $\mathrm{CO}_{2} / \mathrm{Xe}$ dehydration of gases and membrane reactors, etc. Most small-pore zeolite membranes only demonstrated a moderate $\mathrm{O}_{2} / \mathrm{N}_{2}$ ideal selectivity/separation factor, as the pore sizes are not close enough to achieve excellent selectivity from a molecular sieving effect, and the gas pair has limited adsorption selectivity for most zeolites $[97,142]$. Exceptional $\mathrm{O}_{2} / \mathrm{N}_{2}$ separation performance was reported by Yin et al for a stainless-net-supported $\mathrm{NaA}$ zeolite membrane. The membrane demonstrated an $\mathrm{O}_{2}$ permeance of $2.6 \times 10^{-7} \mathrm{~mol} \cdot \mathrm{m}^{-2} \cdot \mathrm{Pa}^{-1} \cdot \mathrm{s}^{-1}$ and an $\mathrm{O}_{2} / \mathrm{N}_{2}$ separation factor of 7 for direct air separation at room temperature. No similar selectivity was reported for LTA-type zeolite membranes, except for an NaA/(polyfurfuryl alcohol) composite membrane reported by wang et al. [143] With the recent development of PIM membranes, which have high $\mathrm{O}_{2}$ permeability and good $\mathrm{O}_{2} / \mathrm{N}_{2}$ selectivity, it is hard for zeolite membranes to compete with polymers for $\mathrm{O}_{2} / \mathrm{N}_{2}$ separation. Some small-pore zeolite pore sizes fall between the kinetic diameter of $\mathrm{Kr}(0.36 \mathrm{~nm})$ and that of Xe $(0.396 \mathrm{~nm})$. This makes small-pore zeolite membranes great candidates for $\mathrm{Kr} / \mathrm{Xe}$ separation. SAPO-34, SSZ-13 and AlPO-18 zeolite membranes have been explored for 
such separations [144-148]. SAPO-34 membranes demonstrated $\mathrm{Kr}$ permeances as high as $1.2 \times 10^{-7} \mathrm{~mol} \cdot \mathrm{m}^{-2} \cdot \mathrm{Pa}^{-1} \cdot \mathrm{s}^{-1}$ and a separation factor of 35 for the separation of $\mathrm{Kr} / \mathrm{Xe}$ with molar compositions close to typical concentrations of these two gases in air [144,145]. Wang et al. demonstrated an ultrahigh selectivity of 51-152, together with a $\mathrm{Kr}$ permeance of $0.7-1.3 \times 10^{-8} \mathrm{~mol} \cdot \mathrm{m}^{-2} \cdot \mathrm{Pa}^{-1} \cdot \mathrm{s}^{-1}$ for high-silica CHA zeolite membranes [148]. The performance was way above that of current polymer membranes. With low Xe permeability, small-pore zeolite membranes are also great for recovering xenon from anesthetic exhaust gas [149]. Besides dehydration of solvents, $\mathrm{NaA}$ zeolite membranes are also great for dehydration of gases, such as $\mathrm{CH}_{4}$ and $\mathrm{H}_{2}[150,151]$. Li et al. used $\mathrm{NaA}$ zeolite membranes in a membrane reactor for hydrogenation to form methanol with water as a byproduct [152]. Substantial increases were observed in both $\mathrm{CO}_{2}$ conversion and methanol yield. The membrane was tested for the separation of an $\mathrm{H}_{2} \mathrm{O} / \mathrm{CO}_{2} / \mathrm{CO} / \mathrm{H}_{2} / \mathrm{MeOH}$ gas mixture $(\mathrm{MeOH}$, methanol) with a composition of $1.77 \pm 0.14 \% / 23.52 \% / 0.98 \% / 73.50 \% / 0.23 \pm 0.02 \%$ at $523 \mathrm{~K}$ and 21 bar. The selectivity (permeance ratio) of $\mathrm{H}_{2} \mathrm{O} / \mathrm{CO}_{2}$ was $\sim 551 \pm 33$. The minimum selectivities of $\mathrm{H}_{2} \mathrm{O} / \mathrm{H}_{2}, \mathrm{H}_{2} \mathrm{O} / \mathrm{CO}$, and $\mathrm{H}_{2} \mathrm{O} / \mathrm{MeOH}$ were 190,170 and 80, respectively. LTA-type zeolite membranes were also used by Inami et al. for $\mathrm{NH}_{3}$ separation for sensor applications [153].

\section{Membrane Synthesis}

\subsection{CHA (High-Silica)}

As discussed previously, CHA-type zeolite membranes have demonstrated great potentials for the separation of $\mathrm{CO}_{2} / \mathrm{CH}_{4}, \mathrm{CO}_{2} / \mathrm{N}_{2}, \mathrm{~N}_{2} / \mathrm{CH}_{4}$ and $\mathrm{H}_{2}$ /hydrocarbons. Representative synthesis conditions for high-silica CHA-type zeolite membranes are summarized in Table 2. The first high-silica CHA-type zeolite membranes, also called SSZ-13 zeolite membranes, were reported by Kalipcilar et al. [56] They used N,N,N-trimethyl-1adamantammonium hydroxide (TMAdaOH) as the OSDA. TMAdaOH was not commercially available at the time. They prepared TMAdaOH by mixing ADA with $\mathrm{KHCO}_{3}$ and methyl iodide in methanol. After reacting for 4 days at room temperature, the product was purified to obtain TMAdaI. It was then ion-exchanged with Dowex $550 \mathrm{~A} \mathrm{OH}^{-}$resin to convert it to TMAdaOH. The SSZ-13 seed crystals were synthesized with a gel comprising 20 TMAdaOH:100 $\mathrm{SiO}_{2}: 2.5 \mathrm{Al}_{2} \mathrm{O}_{3}: 4400 \mathrm{H}_{2} \mathrm{O}: 10 \mathrm{Na}_{2} \mathrm{O}$. Hydrothermal synthesis was carried out at $433 \mathrm{~K}$ for 5 days. After seed-crystal coating on the inner side of the stainless-steel tube, membrane synthesis was conducted at the same conditions as seed crystals. Membrane activation was carried out by calcination in air at $753 \mathrm{~K}$ for $15 \mathrm{~h}$. The membrane had a $\mathrm{CO}_{2}$ permeance of $1.7 \times 10^{-7} \mathrm{~mol} \cdot \mathrm{m}^{-2} \cdot \mathrm{Pa}^{-1} \cdot \mathrm{s}^{-1}$ and a $\mathrm{CO}_{2} / \mathrm{CH}_{4}$ selectivity of 12 , which is much higher than corresponding Knudsen diffusion selectivity. Although the membrane selectivity was only moderate, it pointed out a feasible synthesis route for the preparation of SSZ-13 zeolite membranes, as well as potential applications.

Table 2. CHA-type zeolite membrane synthesis conditions and corresponding separation performance.

\begin{tabular}{|c|c|c|c|c|c|c|c|}
\hline Synthesis Conditions & Substrate & $\delta, \mathrm{um}$ & $\begin{array}{l}P_{\text {feed }} \\
\text { and T }\end{array}$ & A/B Gas & $\begin{array}{c}\mathbf{P}_{\mathrm{m}, \mathrm{A}}, \times 10^{-7} \\
\mathbf{m o l} \cdot \mathbf{m}^{-2} \cdot \mathbf{P a}^{-1} \cdot \mathbf{s}^{-1}\end{array}$ & $\alpha_{\mathrm{A} / \mathrm{B}}$ & Ref. \\
\hline $\begin{array}{c}\text { 20TMAdaOH:100SiO } 2: 2.5 \mathrm{Al}_{2} \mathrm{O}_{3}: 4400 \mathrm{H}_{2} \mathrm{O}: 10 \mathrm{Na}_{2} \mathrm{O} \\
433 \mathrm{~K} \text { for } 5 \text { days }\end{array}$ & Stainless steel tube & $10-40$ & $\begin{array}{l}0.25 \mathrm{MPa}, \\
298 \mathrm{~K}\end{array}$ & $\mathrm{CO}_{2} / \mathrm{CH}_{4}$ & 1.7 & 12 & [56] \\
\hline $\begin{array}{c}\text { 20TMAdaOH:105SiO }{ }_{2}: 0.5025 \mathrm{Al}_{2} \mathrm{O}_{3}: 4400 \mathrm{H}_{2} \mathrm{O}: 10 \mathrm{Na}_{2} \mathrm{O} \text {, } \\
433 \mathrm{~K} \text { for } 6 \text { days }\end{array}$ & $\alpha-\mathrm{Al}_{2} \mathrm{O}_{3}$ hollow fiber & $4-6$ & $\begin{array}{l}0.6 \mathrm{MPa} \\
293 \mathrm{~K}\end{array}$ & $\mathrm{CO}_{2} / \mathrm{CH}_{4}$ & 3 & 42 & [59] \\
\hline 50TMAdaOH: $100 \mathrm{SiO}_{2}: 550 \mathrm{H}_{2} \mathrm{O}: 50 \mathrm{HF}, 423 \mathrm{~K}$ for $120 \mathrm{~h}$ & $\alpha-\mathrm{Al}_{2} \mathrm{O}_{3}$ tube & $\sim 1$ & $\begin{array}{l}0.2 \mathrm{MPa} \\
298 \mathrm{~K}\end{array}$ & $\mathrm{CO}_{2} / \mathrm{CH}_{4}$ & 40 & 130 & [31] \\
\hline 140TMAdaOH: $100 \mathrm{SiO}_{2}: 940 \mathrm{H}_{2} \mathrm{O}: 140 \mathrm{HF}, 433 \mathrm{~K}$ for $18 \mathrm{~h}$ & $\alpha-\mathrm{Al}_{2} \mathrm{O}_{3}$ disk and tube & $<1.5$ & $\begin{array}{l}0.9 \mathrm{MPa}, \\
293 \mathrm{~K}\end{array}$ & $\mathrm{CO}_{2} / \mathrm{CH}_{4}$ & 78 & 32 & [75] \\
\hline $\begin{array}{l}\text { 40TMAdaOH: } 100 \mathrm{SiO}_{2}: 0.5 \mathrm{Al}_{2} \mathrm{O}_{3}: 500 \mathrm{H}_{2} \mathrm{O}: 10 \mathrm{Na}_{2} \mathrm{O} \\
453 \mathrm{~K} \text { for } 12 \mathrm{~h}\end{array}$ & $\alpha-\mathrm{Al}_{2} \mathrm{O}_{3}$ disk & $\sim 1.2$ & $\begin{array}{l}0.1 \mathrm{MPa}, \\
294 \mathrm{~K}\end{array}$ & $\mathrm{CO}_{2} / \mathrm{CH}_{4}$ & 12 & 210 & [72] \\
\hline $\begin{array}{c}\text { 20TMAdaOH:100SiO } 2: 5 \mathrm{Al}_{2} \mathrm{O}_{3}: 8000 \mathrm{H}_{2} \mathrm{O}: 5 \mathrm{Na}_{2} \mathrm{O}, 453 \mathrm{~K} \\
\text { for } 72 \mathrm{~h}\end{array}$ & $\mathrm{Al}_{2} \mathrm{O}_{3}$ monolith & $\sim 3.5$ & $\begin{array}{l}2.0 \mathrm{MPa}, \\
298 \mathrm{~K}\end{array}$ & $\mathrm{CO}_{2} / \mathrm{CH}_{4}$ & 16.3 & 72 & [78] \\
\hline $\begin{array}{c}100 \mathrm{SiO}_{2}: 1 \mathrm{Al}_{2} \mathrm{O}_{3}: 10,000 \mathrm{H}_{2} \mathrm{O}: 35 \mathrm{Na}_{2} \mathrm{O}: 9 \mathrm{~K}_{2} \mathrm{O}, 448 \mathrm{~K} \text { for } \\
1 \text { day }\end{array}$ & $\alpha-\mathrm{Al}_{2} \mathrm{O}_{3}$ disk & $\sim 10$ & $\begin{array}{l}0.1 \mathrm{Mpa}, \\
303 \mathrm{~K}\end{array}$ & $\mathrm{CO}_{2} / \mathrm{CH}_{4}$ & 0.5 & 28.8 & [69] \\
\hline
\end{tabular}


Kosinov et al. slightly modified the synthesis conditions and achieved higher membrane separation performance [59]. The main revisions included: (1) alumina hollow fiber was used as substrate; (2) the seed crystals were ball-milled to smaller size before usage; (3) the $\mathrm{Si} / \mathrm{Al}$ ratio in the gel was increased to 100; (4) the synthesis duration was increased to 6 days. They achieved a $\mathrm{CO}_{2} / \mathrm{CH}_{4}$ separation factor $\sim 40$ and a $\mathrm{CO}_{2}$ permeance $\sim 3 \times 10^{-7} \mathrm{~mol} \cdot \mathrm{m}^{-2} \cdot \mathrm{Pa}^{-1} \cdot \mathrm{s}^{-1}$. Both are higher than the initial SSZ-13 zeolite membrane performance. In another work, they also studied the influence of the $\mathrm{Si} / \mathrm{Al}$ ratio in membrane synthesis gels on membrane quality [57]. For an $\mathrm{Si} / \mathrm{Al}$ ratio between 5 and 100, a higher $\mathrm{Si} / \mathrm{Al}$ resulted in a higher $\mathrm{CO}_{2} / \mathrm{CH}_{4}$ separation factor. However, the highest $\mathrm{H}_{2} \mathrm{O}$ /ethanol selectivity was obtained for an $\mathrm{Si} / \mathrm{Al}$ ratio of 10 . The observation was attributed to the significant difference in water uptake for zeolites with different $\mathrm{Si} / \mathrm{Al}$ ratios. Zeolite with a low $\mathrm{Si} / \mathrm{Al}$ ratio had a high polarity and stronger water adsorption, which contributed to a high water/ethanol separation factor.

Kida et al. developed a high-concentration fluoride-mediated gel for the fabrication of pure silica CHA zeolite membranes [31,79]. The precursor gel had composition of 50TMAdaF: $100 \mathrm{SiO}_{2}: 550 \mathrm{H}_{2} \mathrm{O}$. HF was added to the precursor gel to neutralize the $\mathrm{pH}$. Fluoride anions also served as mineralizing agents. To make the membrane, they first rub-coated the outer surface of the alumina tube with ball-milled seed crystals. In their optimized precursor gel, $0.1 \mathrm{wt}$.\% of seed crystals (to silica in the precursor gel) was added to the precursor gel. Then, the gel paste was daubed on the seeded support to a thickness of 3-5 mm. The gel-coated support tubes were then wrapped with a PTFE tape in order to prevent gel dripping. Hydrothermal synthesis was conducted at $423 \mathrm{~K}$ for $120 \mathrm{~h}$. The membrane achieved a remarkable $\mathrm{CO}_{2}$ permeance of $4.0 \times 10^{-6} \mathrm{~mol} \cdot \mathrm{m}^{-2} \cdot \mathrm{Pa}^{-1} \cdot \mathrm{s}^{-1}$ and a $\mathrm{CO}_{2} / \mathrm{CH}_{4}$ separation factor of 130 at $298 \mathrm{~K}$ with $0.2 \mathrm{MPa}$ feed pressure. When the membrane was tested for a humidified $\mathrm{CO}_{2} / \mathrm{CH}_{4}$ mixture at $298 \mathrm{~K}, \mathrm{CO}_{2}$ permeance dropped to $\sim 3 \%$ of the dry feed case. The decrease in $\mathrm{CO}_{2}$ permeance was much more significant than that of our CHA zeolite membrane (retained $\sim 1 / 3$ of $\mathrm{CO}_{2}$ permeance) synthesized with a non-fluoride-mediated gel [72]. The difference indicates that there might be a chemical difference between membranes synthesized with fluoride- and nonfluoride-mediated gels.

The highest $\mathrm{CO}_{2}$ permeance, together with good $\mathrm{CO}_{2} / \mathrm{CH}_{4}$ selectivity, was achieved by Yu et al. [75] They adopted a delicate substrate-hydrophobization treatment method to prevent the infiltration of zeolite membranes through substrate pores. The rough procedures are shown in Figure 6. The disc and tubular alumina supports were first calcined at $773 \mathrm{~K}$ to remove possible organic contamination. They were then rinsed with deionized water, followed by placement in a filtered $(0.8 \mu \mathrm{m}) 1.0 \mathrm{wt} . \%$ cationic polymer (ATC 4150 , poly(dimethylamineco-epichlorohydrin-co-ethylenediamine)) solution with a $\mathrm{pH}$ of 9.0 for $20 \mathrm{~min}$. The supports were then rinsed with $0.1 \mathrm{M}$ aqueous $\mathrm{NH}_{3}$ solution to remove excess cationic polymer and thoroughly dried. They were then immersed in a filtered $2.5 \mathrm{wt} . \%$ $1 \mathrm{H}, 1 \mathrm{H}, 2 \mathrm{H}, 2 \mathrm{H}$-perfluorodecyltriethoxysilane ethanol solution for $60 \mathrm{~min}$. After rinsing off excess hydrophobic chemicals with ethanol, the supports were thoroughly dried before immersion in $1 \mathrm{wt} . \%$ seed solution for $15 \mathrm{~min}$ for seed coating. They used fluoride-mediated gel solution with a composition of 1.0 $\mathrm{SiO}_{2}: 1.4$ TMAdaF:9.4 $\mathrm{H}_{2} \mathrm{O}$ for membrane synthesis. The synthesis was conducted at $433 \mathrm{~K}$ for $18 \mathrm{~h}$. The membrane demonstrated a $\mathrm{CO}_{2}$ permeance of $7.8 \times 10^{-6} \mathrm{~mol} \cdot \mathrm{m}^{-2} \cdot \mathrm{Pa}^{-1} \cdot \mathrm{s}^{-1}$ and a $\mathrm{CO}_{2} / \mathrm{CH}_{4}$ separation factor of 32 at $293 \mathrm{~K}$ and 9 bar feed pressure. It should be noted that most papers reported $\mathrm{CO}_{2} / \mathrm{CH}_{4}$ separation results under much lower feed pressure. In another work from $\mathrm{Yu}$ and colleagues, they reported a similar $\mathrm{CO}_{2}$ permeance at $0.25 \mathrm{MPa}$ feed pressure but a $\mathrm{CO}_{2} / \mathrm{CH}_{4}$ separation factor of up to $\sim 100$, which was achieved at a feed pressure of $0.5 \mathrm{MPa}$ [32]. These results demonstrate the effectiveness of the hydrophobic treatment for preventing zeolite growth inside substrate pores, thus enhancing membrane permeance.

Our group developed a one-step method for the fabrication of hollow-fiber CHA zeolite membranes [72]. The major advantage of the method is simplicity; no separate seeding step is needed. The precursor gel is a high-concentration version of precursor 
gel used for synthesis of CHA zeolite crystals by Díaz-Cabañas et al. [154] Seed crystals of $\sim 500 \mathrm{~nm}$ in size were directly added to the precursor gel. The seed was $5 \mathrm{wt} . \%$ of the equivalent mass of $\mathrm{SiO}_{2}$ in the gel. In the synthesis, up to 20 hollow-fiber membranes were synthesized in one batch by putting the fibers loosely together in a $\frac{1}{2}$ " diameter Teflon liner. The ratio of precursor gel volume to the membrane surface area was $0.34 \mathrm{~mL}$ gel per $1 \mathrm{~cm}^{2}$ membrane area, which was very efficient for membrane fabrication. The 20-fiber membrane module demonstrated a $\mathrm{CO}_{2}$ permeance of $1.7 \times 10^{-6} \mathrm{~mol} \cdot \mathrm{m}^{-2} \cdot \mathrm{Pa}^{-1} \cdot \mathrm{s}^{-1}$ and a $\mathrm{CO}_{2} / \mathrm{C}_{3} \mathrm{H}_{8}$ ideal selectivity of 21,000 . The high-quality membranes indicated good reproducibility and minimal interference between hollow fibers when they were loosely aligned for synthesis. The synthesis method could be a simple and scalable one for the fabrication of hollow-fiber CHA zeolite membranes. An interesting finding is that both $\mathrm{CO}_{2} / \mathrm{CH}_{4}$ and $\mathrm{CO}_{2} / \mathrm{N}_{2}$ separation factors increased significantly when switching from dry feed to water-vapor-saturated feed. The $\mathrm{CO}_{2} / \mathrm{N}_{2}$ separation factor was up to 30 for humid feed. $\mathrm{CO}_{2}$ permeance dropped to about a third of that for dry feed, which was among the lowest permeance drops for zeolite membranes.

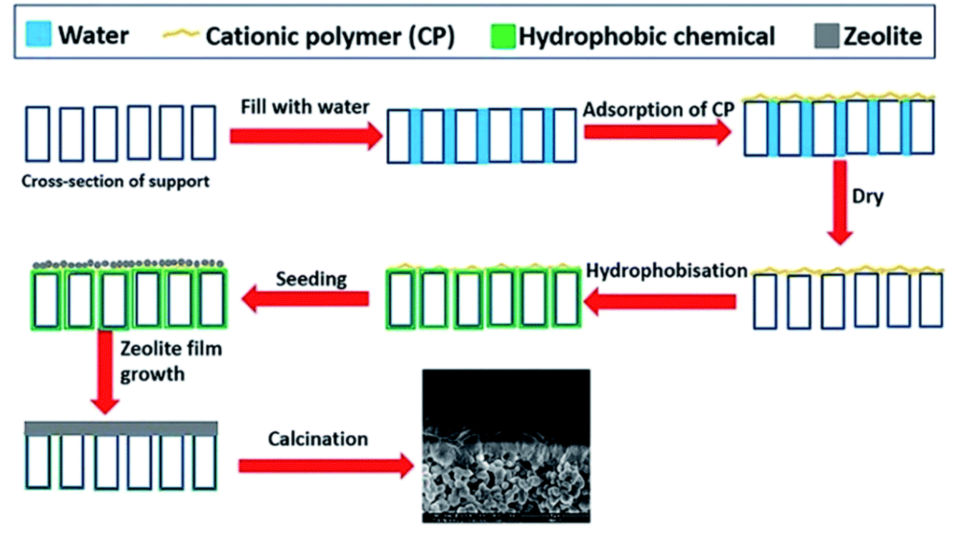

Figure 6. Scheme describing the steps of substrate-hydrophilization treatment to prevent membrane growth inside substrate pores. Reprinted from Yu et al. with permission [75].

Most highly permeable membranes have been synthesized with highly concentrated precursor gel. In a recent work from Li et al. [78], they managed to synthesize a highquality CHA zeolite membrane in a dilute synthesis precursor solution on seven-channel alumina monolith. Secondary growth was conducted with a precursor molar ratio of 20 TMAdaOH:100 $\mathrm{SiO}_{2}: 5 \mathrm{Al}_{2} \mathrm{O}_{3}: 8000 \mathrm{H}_{2} \mathrm{O}: 5 \mathrm{Na}_{2} \mathrm{O}$ at $453 \mathrm{~K}$ for $72 \mathrm{~h}$. The $\mathrm{H}_{2} \mathrm{O} / \mathrm{SiO}_{2}$ ratio in the precursor was 80 , compared to $\sim 5$ in studies by Kida, Yu and our group. [32,73,80] The $\mathrm{Al} / \mathrm{Si}$ molar ratio was also quite high, i.e., 0.1 , compared to 0.01 for our work and no Al for Kida and $\mathrm{Yu}$. Al content is expected to be higher in the membrane, although it was not reported. The membrane only demonstrated a moderate $\mathrm{CO}_{2} / \mathrm{CH}_{4}$ separation factor of about 17, with a $0.2 \mathrm{MPa}$ pressure drop. The authors observed an increasing $\mathrm{CO}_{2} / \mathrm{CH}_{4}$ separation factor with an increasing pressure drop between 0.2 and $1.4 \mathrm{MPa}$. It was explained by that the $\mathrm{CO}_{2}$ adsorption amount increased faster than that of $\mathrm{CH}_{4}$ with increasing pressure, as observed by Kosinov et al. [59] Another finding is that spacer insertion inside the membrane module greatly enhanced $\mathrm{CO}_{2}$ permeance (from $1.01 \times 10^{-6}$ to $1.63 \times 10^{-6} \mathrm{~mol} \cdot \mathrm{m}^{-2} \cdot \mathrm{Pa}^{-1} \cdot \mathrm{s}^{-1}$ ) and $\mathrm{CO}_{2} / \mathrm{CH}_{4}$ separation factor (from 50 to 72 ). This indicates that concentration polarization could not be ignored, even when a feed flow rate as high as 20 SLPM was used. The spacer increased the linear velocity and decreased the effective diameter. It led to a decrease in Re numbers and less concentration polarization effect.

Hasegawa and coworkers reported OSDA-free synthesis of CHA-type zeolite membranes [155]. Only dehydration performance was reported for pervaporation of ethanol solutions. Liu et al. reported OSDA-free synthesis of CHA-type zeolite particles under fluoride-mediated solution [156]. OSDA-free synthesis of CHA zeolite particles and membranes was also studied by Jang et al. [69] More thorough membrane synthesis conditions 
and corresponding gas separation performance were reported. Both particle and membrane synthesis were realized by secondary growth from conventionally synthesized CHA zeolite seeds (with OSDA, denoted as C-SSZ-13). For particle synthesis, precursor with Si/Al ratios of 20,50, 100 and $\infty$ were tried. Only an $\mathrm{Si} / \mathrm{Al}$ ratio of 20 generated pure CHA phase particles. The BET surface area of OSDA-free particles was $\sim 30 \%$ lower than that of C-SSZ13. The $\mathrm{Si} / \mathrm{Al}$ ratio was 4.2, compared to 23 for C-SSZ-13, despite the same Si/Al ratio in the synthesis precursor. Low $\mathrm{Si} / \mathrm{Al}$ ratio in resulting crystals is commonly observed for OSDAfree synthesis, as the incorporation rate of $\mathrm{Al}$ and $\mathrm{Si}$ into the framework differs significantly. For membrane synthesis, precursor with an Si/Al ratio of 50 was found to generate higher membrane quality compared to precursor with an $\mathrm{Si} / \mathrm{Al}$ ratio of 20 . The synthesis duration was further optimized, and one-day synthesis was determined as optimal. The membrane demonstrated a $\mathrm{CO}_{2} / \mathrm{N}_{2}$ separation factor similar to that of membranes synthesized with SDA for dry $\mathrm{CO}_{2} / \mathrm{N}_{2}$ separation. The interesting observation is that both $\mathrm{CO}_{2}$ permeance and $\mathrm{CO}_{2} / \mathrm{N}_{2}$ separation factor increased then decreased when temperature was increased from room temperature to up to $473 \mathrm{~K}$. For wet $\mathrm{CO}_{2} / \mathrm{N}_{2}$ feed, $\mathrm{CO}_{2}$ permeance was below the detection limit of $10^{-9} \mathrm{~mol} \cdot \mathrm{m}^{-2} \cdot \mathrm{Pa}^{-1} \cdot \mathrm{s}^{-1}$ at room temperature and $323 \mathrm{~K}$. However, at $398 \mathrm{~K}$, the membrane had a $\mathrm{CO}_{2} / \mathrm{N}_{2}$ separation factor of $10.0 \pm 1.0$, with a corresponding $\mathrm{CO}_{2}$ permeance of $7.5 \times 10^{-8} \mathrm{~mol} \cdot \mathrm{m}^{-2} \cdot \mathrm{Pa}^{-1} \cdot \mathrm{s}^{-1}$. Good $\mathrm{CO}_{2} / \mathrm{CH}_{4}$ separation factors, up to $28.8 \pm 6.9$ at $303 \mathrm{~K}$, were obtained for dry feed. For wet $\mathrm{CO}_{2} / \mathrm{CH}_{4}$ feed, there was an appreciable decrease in both permeance and selectivity, making it less attractive for direct separation of wet feed without a dehydration process.

\section{2. $D D R$}

DDR-type zeolite membranes demonstrated similar separation selectivities to $\mathrm{CHA}$ zeolite membranes for the separation of $\mathrm{CO}_{2} / \mathrm{CH}_{4}, \mathrm{CO}_{2} / \mathrm{N}_{2}$ and $\mathrm{H}_{2} / \mathrm{CH}_{4}$, although their permeance was typically lower, limited by the two-dimensional pore channels. Representative synthesis conditions for DDR-type zeolite membranes are summarized in Table 3. DDR-type, also referred as DD3R or ZSM-58, zeolite membranes were first reported by Tomita et al. through the secondary growth method [98]. A lengthy 25-day synthesis was used for preparation of the seed crystal according to Exter et al. [157] The precursor solution preparation steps were also quite complex in order to have good control of the mixing, hydrolysis and condensation rates. After mixing ADA, EDA and water, the mixture was shaken for $1 \mathrm{~h}$ with a shaking machine. It was then heated to $368 \mathrm{~K}$ for $1 \mathrm{~h}$ under stirring, the mixture was then cooled down in ice/water bath, and TMOS was added dropwise while vigorously stirring the solution. The mixture was then heated again to $368 \mathrm{~K}$ until the solution became clear. The final precursor had a composition of 47ADA: $100 \mathrm{SiO}_{2}: 404 \mathrm{EDA}: 11,240 \mathrm{H}_{2} \mathrm{O}$. Hydrothermal synthesis was conducted at $433 \mathrm{~K}$ for 25 days. The alumina tube was coated with seed crystals by dip coating. The membrane synthesis precursor had a composition of $9 \mathrm{ADA}: 100 \mathrm{SiO}_{2}: 150 \mathrm{EDA}: 4000 \mathrm{H}_{2} \mathrm{O}$. Hydrothermal synthesis was conducted at $423 \mathrm{~K}$ for $48 \mathrm{~h}$. The membrane was activated by calcination at $973 \mathrm{~K}$ for $5 \mathrm{~h}$. The membrane demonstrated an excellent $\mathrm{CO}_{2} / \mathrm{CH}_{4}$ separation factor of 220 and $\mathrm{CO}_{2}$ permeance of $0.4 \times 10^{-7} \mathrm{~mol} \cdot \mathrm{m}^{-2} \cdot \mathrm{Pa}^{-1} \cdot \mathrm{s}^{-1}$ at $301 \mathrm{~K}$ and $0.5 \mathrm{MPa}$ feed pressure. Moreover, the permeance of the pure silica membrane decreased moderately ( $\sim 40 \%$ decrease) after adding 3.3\% water in the feed. At $373 \mathrm{~K}$, water vapor in the feed was not found to influence gas separation performance. The results indicate that the membrane is feasible for direct separation of humid mixtures.

Our group tried to simplify both the seed crystal preparation and membrane synthesis procedures. The required synthesis duration could be cut from over 20 days to 4 days. Through crystal synthesis studies, we found that ball-milled sigma-1 crystals served very well as seeds for secondary growth of DDR zeolite [158]. By tuning the precursor $\mathrm{pH}$, three sets of synthesis conditions were found to be able to generate pure DDR zeolite. Ball-milled Sigma-1 seeds and the highly alkaline precursor (15ADA:100SiO $2: 135 \mathrm{EDA}: 11,240 \mathrm{H}_{2} \mathrm{O}: 15 \mathrm{Na}_{2} \mathrm{O}$ ) were used for secondary growth of DDR membrane [97]. The required duration of seed synthesis was reduced to 3 days, and membrane synthesis duration was reduced to $24 \mathrm{~h}$. A continuous 
membrane was obtained, evidenced by very low He permeance before activation. However, the membrane-activation step was susceptible to crack formation, which was observed by different groups. The membrane had no $\mathrm{CO}_{2} / \mathrm{CH}_{4}$ selectivity as gases mainly permeated through the cracks by non-selective Knudsen or gaseous diffusion. Amorphous silica deposition through counter diffusion of TMOS and water was used to repair the cracks. After crack repair, a $\mathrm{CO}_{2} / \mathrm{CH}_{4}$ selectivity 100 was achieved. Our work provides a facile route for DDR zeolite membrane fabrication and effective methods for crack repair to achieve selective membranes.

Table 3. DDR-type zeolite membrane synthesis conditions and corresponding separation performance.

\begin{tabular}{|c|c|c|c|c|c|c|c|}
\hline Synthesis Conditions & Substrate & $\begin{array}{l}\delta, \\
\text { um }\end{array}$ & 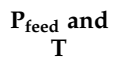 & A/B Gas & $\begin{array}{l}P_{\mathrm{m}, \mathrm{A}}, \times 10^{-7} \\
\mathbf{m o l} \cdot \mathbf{m}^{-2} \cdot \mathbf{P a}^{-1} \cdot \mathbf{s}^{-1}\end{array}$ & $\alpha_{\mathrm{A} / \mathrm{B}}$ & Ref. \\
\hline 9ADA:100SiO $2: 150 E D A: 4000 \mathrm{H}_{2} \mathrm{O}, 423 \mathrm{~K}$ for $48 \mathrm{~h}$ & $\alpha-\mathrm{Al}_{2} \mathrm{O}_{3}$ tube & $5-10$ & $\begin{array}{l}0.5 \mathrm{MPa} \\
301 \mathrm{~K}\end{array}$ & $\mathrm{CO}_{2} / \mathrm{CH}_{4}$ & 0.4 & 220 & [98] \\
\hline 15ADA:100SiO $2: 135 E D A: 11,240 \mathrm{H}_{2} \mathrm{O}: 15 \mathrm{Na}_{2} \mathrm{O}, 433 \mathrm{~K}$ for $24 \mathrm{~h}$ & $\alpha-\mathrm{Al}_{2} \mathrm{O}_{3}$ disk & $\sim 10$ & $\begin{array}{l}0.2 \mathrm{MPa}, \\
298 \mathrm{~K}\end{array}$ & $\mathrm{CO}_{2} / \mathrm{CH}_{4}$ & 1.8 & 92 & [97] \\
\hline 3ADA: $100 \mathrm{SiO}_{2}: 50 \mathrm{EDA}: 4000 \mathrm{H}_{2} \mathrm{O}, 413 \mathrm{~K}$ for $48 \mathrm{~h}$ & $\alpha-\mathrm{Al}_{2} \mathrm{O}_{3}$ hollow fiber & $5-8$ & $\begin{array}{l}0.2 \mathrm{MPa}, \\
298 \mathrm{~K}\end{array}$ & $\mathrm{CO}_{2} / \mathrm{CH}_{4}$ & 0.35 & 500 & [22] \\
\hline 2.6ADA:2.6KF:100SiO $2: 5200 \mathrm{H}_{2} \mathrm{O}, 473 \mathrm{~K}$ for $72 \mathrm{~h}$ & $\alpha-\mathrm{Al}_{2} \mathrm{O}_{3}$ tube & $\sim 5$ & $\begin{array}{l}1.1 \mathrm{MPa}, \\
298 \mathrm{~K}\end{array}$ & $\mathrm{CO}_{2} / \mathrm{CH}_{4}$ & 1.2 & 270 & [85] \\
\hline 17.5MTI:70SiO $2: 2800 \mathrm{H}_{2} \mathrm{O}: 23 \mathrm{NaOH}, 403 \mathrm{~K}$ for 10 days & $\alpha-\mathrm{Al}_{2} \mathrm{O}_{3}$ disk & $\sim 7$ & $\begin{array}{l}0.1 \mathrm{MPa}, \\
303 \mathrm{~K}\end{array}$ & $\mathrm{CO}_{2} / \mathrm{CH}_{4}$ & 1 & 673 & [77] \\
\hline $\begin{array}{c}\text { 15ADA: } 100 \mathrm{SiO}_{2}: 140 \mathrm{EDA}: 10,000 \mathrm{H}_{2} \mathrm{O}: 15 \mathrm{Na}_{2} \mathrm{O}, 453 \mathrm{~K} \text { for } 1 \mathrm{~h} \text { by } \\
\text { microwave }\end{array}$ & ceramic tube & $\sim 1$ & $\begin{array}{l}0.24 \mathrm{MPa} \\
298 \mathrm{~K}\end{array}$ & $\mathrm{CO}_{2} / \mathrm{CH}_{4}$ & 4.9 & 199 & [91] \\
\hline 50ADA:20TEAOH: $100 \mathrm{SiO}_{2}: 10,000 \mathrm{H}_{2} \mathrm{O}, 493 \mathrm{~K}$ for $2.5 \mathrm{~h}$ & ceramic tube & $\sim 1.5$ & $\begin{array}{l}0.24 \mathrm{MPa} \\
298 \mathrm{~K}\end{array}$ & $\mathrm{CO}_{2} / \mathrm{CH}_{4}$ & 4.1 & 160 & [93] \\
\hline N.A. & ceramic monolith & N.A. & $0.4 \mathrm{MPa}$ & $\mathrm{CO}_{2} / \mathrm{CH}_{4}$ & $>5$ & $>160$ & [88] \\
\hline 3ADA:100SiO $2: 50 E D A: 4000 \mathrm{H}_{2} \mathrm{O}: 1.54 \mathrm{Na}_{2} \mathrm{O}, 413 \mathrm{~K}$ for $44 \mathrm{~h}$ & $\alpha-\mathrm{Al}_{2} \mathrm{O}_{3}$ hollow fiber & $5-6$ & $\begin{array}{l}0.2 \mathrm{MPa} \\
298 \mathrm{~K}\end{array}$ & $\mathrm{CO}_{2} / \mathrm{CH}_{4}$ & 1.55 & 447 & {$[96]$} \\
\hline
\end{tabular}

Note: all membranes were synthesized by the second growth method.

Wang et al. developed their own clear precursor for membrane synthesis, and more importantly, the ozone membrane-activation method to prevent crack formation [22]. The precursor had molar composition of $3 \mathrm{ADA}: 100 \mathrm{SiO}_{2}: 50 \mathrm{EDA}: 4000 \mathrm{H}_{2} \mathrm{O}$. They adopted a low-temperature ozone activation method and successfully avoided crack formation. The low-temperature activation avoided stress buildup between substrate and zeolite film when heating the membrane to high temperatures. The activation was achieved by exposing the membrane to flowing $\mathrm{O}_{3} / \mathrm{O}_{2}$ gas at $473 \mathrm{~K}$ for $60 \mathrm{~h}$. A higher $\mathrm{CO}_{2} / \mathrm{CH}_{4}$ separation factor of 500 was achieved, compared to membranes activated by calcination. An interesting finding is that the membrane permeance demonstrated a more significant $\mathrm{CO}_{2}$ permeance drop $(88 \%)$ after adding water vapor to the feed at $303 \mathrm{~K}$, compared to calcined membranes. A similar permeance drop was also reported by Jeong et al. [77]. With water adsorption and permeation test results, Jeong and colleagues concluded that the more pronounced water-vapor influence was mainly because the permeation was inhibited by the water molecules adsorbed in the micropores. Hayakawa and Hemeno used halogen-salt-mediated solution for fabrication of a DDR zeolite membrane. $\mathrm{KF}, \mathrm{KCl}$, $\mathrm{KBr}, \mathrm{NaF}, \mathrm{NaCl}$ and $\mathrm{NaBr}$ were used as mineralizing agents [85]. They also optimized the mineralizing agent-to-silica ratio and OSDA-to-silica ratio in the precursor solution. For a range of synthesis conditions, they managed to achieve a highly selective DDR zeolite membrane. Their work proved the feasibility of using halogen-salt-mediated solution for the fabrication of DDR zeolite membranes.

Jeong et al. conducted interesting research on heteroepitaxial growth of DDR zeolite membranes $[77,99]$. Methyltropinium iodide (MTI) was used as OSDA instead of ADA. The authors demonstrated influence of different membrane-activation methods on membrane quality and achieved a $\mathrm{CO}_{2} / \mathrm{CH}_{4}$ selectivity over 500 . They used an SSZ-13 (CHA-type) seed layer for secondary growth of a DDR zeolite membrane. As shown in Figure 7, the results demonstrated that DDR zeolite structure had very good compatibility with CHA zeolite. Continuous membranes were successfully obtained. Electron diffraction patterns and XRD patterns proved the coexistence of CHA and DDR structures, as well as a DDR zeolite membrane grown on top of a CHA zeolite layer. They further compared 
three membrane activation conditions: calcination in air for $12 \mathrm{~h}$ at $823 \mathrm{~K}$, calcination in $\mathrm{O}_{2}$ for $80 \mathrm{~h}$ at $723 \mathrm{~K}$ and calcination in $\mathrm{O}_{3}$ at $523 \mathrm{~K}$ for $40 \mathrm{~h}$. The low-temperature $\mathrm{O}_{3}$-activated membranes demonstrated the highest $\mathrm{CO}_{2} / \mathrm{CH}_{4}$ separation factor among the membranes. For separation tests with dry $\mathrm{CO}_{2} / \mathrm{CH}_{4}$ feed at $323 \mathrm{~K}, \mathrm{O}_{3}$-activated membranes had the highest $\mathrm{CO}_{2} / \mathrm{CH}_{4}$ separation factor of $523 \pm 96$, compared to $243 \pm 74,412 \pm 100$ for air and $\mathrm{O}_{2}$-activated membranes, respectively. The difference in separation factor between the membranes is consistent with the fluorescence confocal optical microscopy (FCOM) results. The $\mathrm{O}_{3}$-activated membrane only had sporadic and isolated defects, while the air-activated membrane had interconnected cracks, and the $\mathrm{O}_{2}$-activated membrane had cracks that were not fully connected.

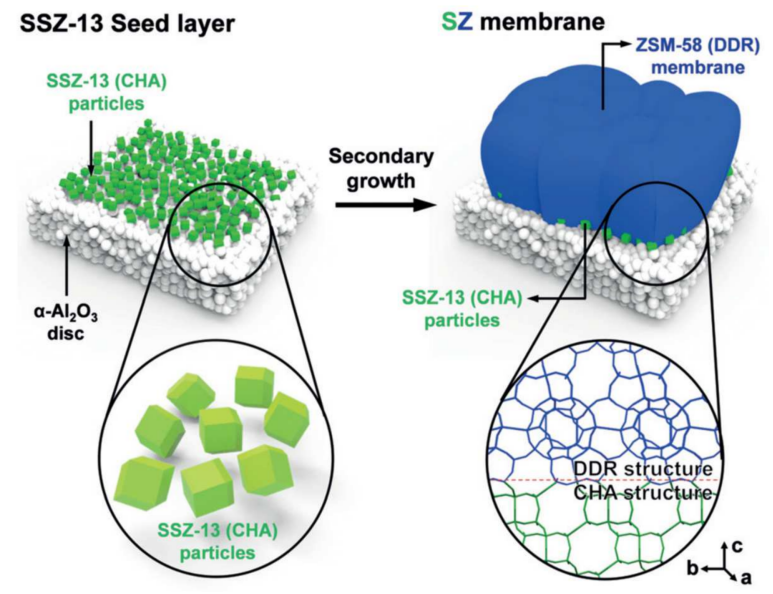

Figure 7. Schematic illustration of heteroepitaxial growth of a DDR-type zeolite membrane on an SSZ-13 zeolite seed layer. Reprinted from Jeong et al. with permission [99].

Wang et al. managed to synthesize a thin DDR zeolite membrane within an hour by microwave heating [91]. Microwave heating has been used for the synthesis of LTA, MFI and AFI membranes [159]. It is known to shorten the synthesis duration because of accelerated nucleation and crystallization. It is still very remarkable to be able to reduce the synthesis duration to within an hour. The continuous zeolite film has a thickness of less than $1.5 \mu \mathrm{m}$, one of the thinnest for DDR membranes. The thin membrane contributed to a high $\mathrm{CO}_{2}$ permeance $\sim 5 \times 10^{-7} \mathrm{~mol} \cdot \mathrm{m}^{-2} \cdot \mathrm{Pa}^{-1} \cdot \mathrm{s}^{-1}$. In another study by the Zhang group, they studied a co-template strategy the synthesis of DDR zeolite membranes. Tetraethylammonium hydroxide (TEAOH), an OSDA commonly used for the synthesis of SAPO-34 zeolite, was used as secondary template, in addition to ADA. According to the authors, TEAOH served as mineralizing agent. They used conventional heating instead of microwave heating. Still, a synthesis duration as short as $2.5 \mathrm{~h}$ was achieved without comprising membrane quality. The facile synthesis was mainly a result of a much higher synthesis temperature $(493 \mathrm{~K})$. Although it is the general understanding that increasing synthesis temperature could shorten the duration of membrane synthesis, it is not always straightforward to do so, particularly for membranes susceptible to impurity formation, such as the SGT and DOH impurity phases for DDR membranes. This work greatly broadened the workable synthesis conditions for DDR zeolite membranes.

It is worth noting that there are continuous efforts towards scaling up DDR zeolite membranes. JGC Corporation (Yokohama, Japan) and NGK Insulators, Ltd. (Nagoya, Japan) developed the world's largest DDR membrane with NGK's monolith ceramic substrate [88,90]. As shown in Figure 8, the monolith membrane has an O.D. of $18 \mathrm{~cm}$, a length of $1 \mathrm{~m}$ and 1600 channels. The total membrane area was $12 \mathrm{~m}^{2}$, which is over 200-300 times larger than conventional tubular-type zeolite membranes of the same length. At a feed pressure of $0.3 \mathrm{MPag}$, the membrane achieved $\mathrm{CO}_{2}$ permeance $>5 \times 10^{-7} \mathrm{~mol} \cdot \mathrm{m}^{-2} \cdot \mathrm{Pa}^{-1} \cdot \mathrm{s}^{-1}$ and $\mathrm{CO}_{2} / \mathrm{CH}_{4}$ selectivity $>170$. At a feed pressure of $8.0 \mathrm{MPag}$ and $318 \mathrm{~K}$, the membrane still demonstrated a $\mathrm{CO}_{2} / \mathrm{CH}_{4}$ selectivity exceeding 100 for feed gas composed of 
$70 \mathrm{~mol} \% \mathrm{CO}_{2}$, which demonstrated great feasibility for high operating pressure in industrial applications. The Gu group of Nanjing Tech University also tried to scale up DDR membrane fabrication on hollow-fiber support [96]. The four-channel $\alpha-\mathrm{Al}_{2} \mathrm{O}_{3}$ hollowfiber supports have $3.8 \mathrm{~mm}$ O.D., $0.9 \mathrm{~mm}$ I.D., $~ 50 \%$ porosity and an average pore size of $200 \mathrm{~nm}$. They tried to optimize alkalinity of the synthesis solution and managed to synthesize 17 membranes in one batch. The membranes had a total membrane area of $406 \mathrm{~cm}^{2}$. Among the 17 membranes, 14 demonstrated a $\mathrm{CO}_{2} / \mathrm{CH}_{4}$ separation factor higher than 100. The remaining three membranes had a decent $\mathrm{CO}_{2} / \mathrm{CH}_{4}$ separation factor of 43 , 31 and 18.

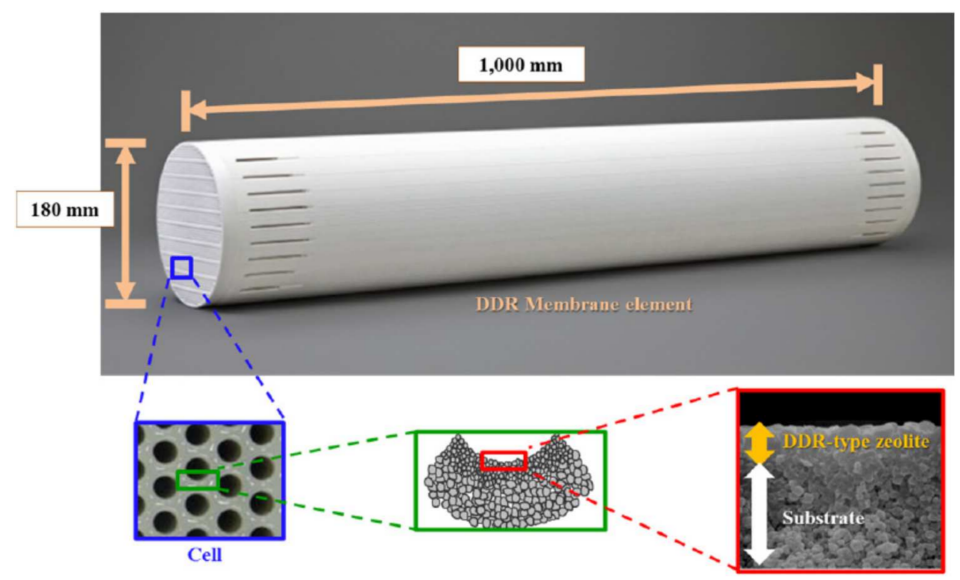

Figure 8. DDR zeolite membrane on monolith support. Reprinted from Hasegawa et al. with permission [88].

\subsection{LTA}

LTA-type zeolite membrane is perhaps the most mature among all zeolite membranes. It demonstrated great dehydration performance but moderate gas separation performance, with the exception for $\mathrm{O}_{2} / \mathrm{N}_{2}, \mathrm{H}_{2} / \mathrm{C}_{3} \mathrm{H}_{8}$ and $\mathrm{H}_{2} / \mathrm{CO}_{2}$ separations. The first industrial application of NaA membrane was reported 20 years ago [160]. Since then, more applications have been found, although the primary application is still solvent dehydration by pervaporation. The membranes are typically synthesized with highly alkaline solution without OSDA and have a very low $\mathrm{Si} / \mathrm{Al}$ ratio (close to 1 ) in the membrane. The membranes tend to be very hydrophilic and great for dehydration applications because of stronger adsorption of water over other solvents and/or molecular sieving effects. LTA membranes are also studied for gas separations. In an early work from the Kita group [161], the membrane demonstrated a water/ethanol separation factor over 10,000 and high water permeance. Due to the close-to-unity $\mathrm{Si} / \mathrm{Al}$ ratio, the membrane demonstrated no gas permeance without complete drying. After drying, the membrane displayed gas permeation behavior attributed to Knudsen diffusion, i.e., no or low selectivity. Based on the results, the authors thought that Knudsen diffusion through the non-zeolitic pores is predominant, and the contribution of zeolitic pores is minimum for completely dried NaA membranes. For pervaporation, however, non-zeolitic pores will be blocked because of water adsorption and condensation. It is challenging to achieve LTA-type zeolite membranes with excellent gas separation characteristics, despite their excellent performance for solvent dehydration.

A few representative gas separation LTA membrane-synthesis conditions and separation performance are summarized in Table 4. One of the most attractive separation performances was reported by Yin et al. [162] The NaA zeolite membrane demonstrated great $\mathrm{O}_{2}$ permeance and $\mathrm{O}_{2} / \mathrm{N}_{2}$ separation factor, which are attractive for commercial application. The stainless-steel net support had an aperture about $50 \times 50 \mu \mathrm{m}$. Growing zeolite membrane on supports with such large pores is challenging. The authors first soaked the stainless-steel net in a surfactant solution to make it hydrophobic. Then, aqueous suspension with $\mathrm{NaA}$ crystals was put on top of the net, and the surface tension was 
able to retain the solution on top of the net. A smooth seed layer formed on the net after drying and heat treatment in a furnace. Secondary growth was then conducted with a precursor molar composition of $1.12 \mathrm{SiO}_{2}: 1 \mathrm{Al}_{2} \mathrm{O}_{3}: 2.55 \mathrm{Na}_{2} \mathrm{O}: 1800 \mathrm{H}_{2} \mathrm{O}$ at $358 \mathrm{~K}$ for 7 days. After cleaning and drying, the membrane was thoroughly dried at $373 \mathrm{~K}$ and $0.1 \mathrm{~Pa}$ overnight. The membrane demonstrated an $\mathrm{O}_{2} / \mathrm{N}_{2}$ separation factor $\sim 7$ and an $\mathrm{O}_{2}$ permeance of about $2.6 \times 10^{-7} \mathrm{~mol} \cdot \mathrm{m}^{-2} \cdot \mathrm{Pa}^{-1} \cdot \mathrm{s}^{-1}$ for direct air separation at room temperature. $\mathrm{O}_{2} / \mathrm{N}_{2}$ separation is considered one of the most challenging separations due the similar size and physical properties of $\mathrm{O}_{2}$ and $\mathrm{N}_{2}$. This is one of the best $\mathrm{O}_{2} / \mathrm{N}_{2}$ separation performances reported so far for any membrane. However, there was not any follow-up report on recent advancements in the membrane.

Table 4. LTA-type zeolite membrane synthesis conditions and corresponding separation performance.

\begin{tabular}{|c|c|c|c|c|c|c|c|}
\hline Synthesis Conditions & Substrate & $\delta$, um & $\begin{array}{l}P_{\text {feed }} \\
\text { and T }\end{array}$ & A/B Gas & $\begin{array}{c}\mathbf{P}_{\mathrm{m}, \mathrm{A}}, \times 10^{-7} \\
\mathbf{m o l} \cdot \mathbf{m}^{-2} \cdot \mathbf{P a}^{-1} \cdot \mathbf{s}^{-1}\end{array}$ & $\alpha_{\mathrm{A} / \mathrm{B}}$ & Ref. \\
\hline $\begin{array}{c}1.12 \mathrm{SiO}_{2}: 1 \mathrm{Al}_{2} \mathrm{O}_{3}: 2.55 \mathrm{Na}_{2} \mathrm{O}: 1800 \mathrm{H}_{2} \mathrm{O}, 358 \mathrm{~K} \text { for } \\
7 \text { days by } 2 \text { nd growth }\end{array}$ & Stainless-steel net & N.A. & $\begin{array}{l}0.1 \mathrm{MPa}, \\
\text { RT }\end{array}$ & $\mathrm{O}_{2} / \mathrm{N}_{2}$ & 2.6 & 7 & [162] \\
\hline $\begin{array}{l}5 \mathrm{SiO}_{2}: \mathrm{Al}_{2} \mathrm{O}_{3}: 50 \mathrm{Na}_{2} \mathrm{O}: 1000 \mathrm{H}_{2} \mathrm{O} \text { at } 363 \mathrm{~K} \text { for } 25 \mathrm{~min} \\
\text { with microwave by in situ method. }\end{array}$ & $\alpha-\mathrm{Al}_{2} \mathrm{O}_{3}$ disk and tube & $\sim 5$ & $\begin{array}{l}0.2 \mathrm{MPa} \\
293 \mathrm{~K}\end{array}$ & $\mathrm{H}_{2} / \mathrm{C}_{3} \mathrm{H}_{8} *$ & 1.71 & 9.17 & [163] \\
\hline $\begin{array}{c}1 \mathrm{P}_{2} \mathrm{O}_{5}: 1 \mathrm{Al}_{2} \mathrm{O}_{3}: 0.5 \mathrm{~K} 222: 0.5 \mathrm{HF}: 300 \mathrm{H}_{2} \mathrm{O}, 473 \mathrm{~K} \text { for } 5 \mathrm{~h} \\
\text { by 2nd growth }\end{array}$ & $\alpha-\mathrm{Al}_{2} \mathrm{O}_{3}$ disk & $10 \sim 20$ & $\begin{array}{l}0.1 \mathrm{MPa}, \\
293 \mathrm{~K}\end{array}$ & $\mathrm{H}_{2} / \mathrm{C}_{3} \mathrm{H}_{8} *$ & 2 & 146 & [16] \\
\hline $\begin{array}{l}\text { 0.67TEOS: } 0.33 \mathrm{GeO}_{2}: 0.25 \mathrm{~K} 222: 0.25 \mathrm{TMAOH} \\
: 0.5 \mathrm{HF}: 60 \mathrm{H}_{2} \mathrm{O}, 423 \mathrm{~K} \text { for } 3 \mathrm{~d} \text { by } 2 \text { nd growth }\end{array}$ & $\alpha-\mathrm{Al}_{2} \mathrm{O}_{3}$ disk & $\sim 12$ & $\begin{array}{l}0.1 \mathrm{MPa}, \\
573 \mathrm{~K}\end{array}$ & $\mathrm{H}_{2} / \mathrm{C}_{3} \mathrm{H}_{8}$ & 3.64 & 127 & [132] \\
\hline $\begin{array}{c}50 \mathrm{Na}_{2} \mathrm{O}: 1 \mathrm{Al}_{2} \mathrm{O}_{3}: 5 \mathrm{SiO}_{2}: 1000 \mathrm{H}_{2} \mathrm{O}, 333 \mathrm{~K} \text { for } 24 \mathrm{~h} \text { by in } \\
\text { situ method }\end{array}$ & $\alpha-\mathrm{Al}_{2} \mathrm{O}_{3}$ disk & $\sim 3$ & $\begin{array}{l}0.1 \mathrm{MPa}, \\
293 \mathrm{~K}\end{array}$ & $\mathrm{H}_{2} / \mathrm{C}_{3} \mathrm{H}_{6}$ & 1.74 & 36.8 & [115] \\
\hline $\begin{array}{c}50 \mathrm{Na}_{2} \mathrm{O}: 1 \mathrm{Al}_{2} \mathrm{O}_{3}: 5 \mathrm{SiO}_{2}: 1000 \mathrm{H}_{2} \mathrm{O}, 333 \mathrm{~K} \text { for } 24 \mathrm{~h} \text { by in } \\
\text { situ method, Ag exchanged }\end{array}$ & $\alpha-\mathrm{Al}_{2} \mathrm{O}_{3}$ tube & 4.5 & $\begin{array}{l}0.3 \mathrm{Mpa}, \\
323 \mathrm{~K}\end{array}$ & $\mathrm{H}_{2} / \mathrm{C}_{3} \mathrm{H}_{8}$ & 1.6 & 120.8 & [164] \\
\hline $\begin{array}{c}50 \mathrm{Na}_{2} \mathrm{O}: 1 \mathrm{Al}_{2} \mathrm{O}_{3}: 2.5 \mathrm{SiO}_{2}: 1000 \mathrm{H}_{2} \mathrm{O}, 15 \text { days under } \\
\text { sonication by 2nd growth }\end{array}$ & clay $-\mathrm{Al}_{2} \mathrm{O}_{3}$ tube & 15 & $\begin{array}{l}0.2 \mathrm{Mpa}, \\
303 \mathrm{~K}\end{array}$ & $\mathrm{CO}_{2} / \mathrm{CH}_{4}$ & 23 & 20.9 & [101] \\
\hline
\end{tabular}

* denotes results from single gas permeation tests.

Li et al. developed a new method-in situ aging-microwave synthesis-for synthesis $\mathrm{NaA}$ zeolite membranes [163]. They first prepared a clear solution with a molar composition of $5 \mathrm{SiO}_{2}: \mathrm{Al}_{2} \mathrm{O}_{3}: 50 \mathrm{Na}_{2} \mathrm{O}: 1000 \mathrm{H}_{2} \mathrm{O}$. After soaking the support in the solution, the vessel was put in a conventional oven and aged at $323 \mathrm{~K}$ for $7 \mathrm{~h}$. Then, crystallization was carried out in a microwave oven at $363 \mathrm{~K}$ for $25 \mathrm{~min}$. The membrane demonstrated excellent selectivity, i.e., over 10,000, for pervaporative dehydration of ethanol (90 wt.\%)/water solution. For single-gas permeation tests, the membrane demonstrated an $\mathrm{H}_{2}$ permeance of $1.71 \times 10^{-7} \mathrm{~mol} \cdot \mathrm{m}^{-2} \cdot \mathrm{Pa}^{-1} \cdot \mathrm{s}^{-1}$ and an $\mathrm{H}_{2} / \mathrm{C}_{3} \mathrm{H}_{8}$ ideal selectivity of 9.17 , which is significantly higher than the Knudsen diffusion selectivity of 4.69 . The results demonstrated the feasibility of the "in situ aging-microwave synthesis" method for high-quality membrane fabrication. However, the gas separation potential was limited or not fully explored.

Huang and coworkers reported the synthesis of an aluminophosphate $\left(\mathrm{AlPO}_{4}\right)$ form of an LTA-type zeolite membrane [16]. With $\mathrm{Al}$ and $\mathrm{P}$ tetrahedra balancing the charge for one another, the framework is neutral and cation-free. The membrane was prepared by dip coating the $\alpha-\mathrm{Al}_{2} \mathrm{O}_{3}$ disk with ALPO-form seed crystals. A membrane synthesis gel with a molar ratio of $1 \mathrm{P}_{2} \mathrm{O}_{5}: 1 \mathrm{Al}_{2} \mathrm{O}_{3}: 0.5 \mathrm{~K} 222: 0.5 \mathrm{HF}: 300 \mathrm{H}_{2} \mathrm{O}$ was used. 4,7,13,16,21,24-Hexaoxa1,10-diazabicyclo[8.8.8]hexacosane (K222) was used as the OSDA. The support was placed horizontally in the autoclave, and hydrothermal treatment was conducted for $5 \mathrm{~h}$ at $473 \mathrm{~K}$. The membrane was activated by calcination at $823 \mathrm{~K}$ for $8 \mathrm{~h} . \mathrm{H}_{2}, \mathrm{CO}_{2}, \mathrm{O}_{2}, \mathrm{CH}_{4}$ and $\mathrm{C}_{3} \mathrm{H}_{8}$ single-gas permeances were tested. The membrane demonstrated an $\mathrm{H}_{2}$ permeance larger than $2 \times 10^{-7} \mathrm{~mol} \cdot \mathrm{m}^{-2} \cdot \mathrm{Pa}^{-1} \cdot \mathrm{s}^{-1}$ and an $\mathrm{H}_{2} / \mathrm{C}_{3} \mathrm{H}_{8}$ ideal selectivity of 146 , which indicated good membrane quality. The membrane demonstrated a slight $\mathrm{CH}_{4}$ ideal selectivity for $\mathrm{CO}_{2} / \mathrm{CH}_{4}$, unlike some other small-pore zeolite membranes. This might be a result of slightly larger pore size for LTA-type zeolites. Huang and Caro also reported the synthesis of an ITQ-29 $\left(\mathrm{SiO}_{2}-\mathrm{GeO}_{2}\right.$ form LTA) zeolite membrane [132]. ITQ-29 seeds were prepared with precursor gel composed of 0.67TEOS:0.33GeO $2: 0.25 \mathrm{~K} 222: 0.25 \mathrm{TMAOH}: 0.5 \mathrm{HF}: 30 \mathrm{H}_{2} \mathrm{O}$. The hydrothermal synthesis was conducted at $423 \mathrm{~K}$ for $6 \mathrm{~h}$. The seed-coated $\alpha-\mathrm{Al}_{2} \mathrm{O}_{3}$ disk was then used for secondary growth of a membrane at $423 \mathrm{~K}$ for 3 days. The membrane synthesis gel had a molar ratio of $0.67 \mathrm{TEOS}: 0.33 \mathrm{GeO}_{2}: 0.25 \mathrm{~K} 222: 0.25 \mathrm{TMAOH}: 0.5 \mathrm{HF}: 60 \mathrm{H}_{2} \mathrm{O}$. 
$\mathrm{H}_{2}, \mathrm{CO}_{2}, \mathrm{~N}_{2}, \mathrm{CH}_{4}$ and $\mathrm{C}_{3} \mathrm{H}_{8}$ single-gas permeance were measured at $573 \mathrm{~K} . \mathrm{H}_{2} / \mathrm{CO}_{2}$ and $\mathrm{H}_{2} / \mathrm{C}_{3} \mathrm{H}_{8}$ demonstrated ideal selectivity of 7.8 and 145.1, respectively. An $\mathrm{H}_{2}$ permeance of $3.64 \times 10^{-7} \mathrm{~mol} \cdot \mathrm{m}^{-2} \cdot \mathrm{Pa}^{-1} \cdot \mathrm{s}^{-1}$ and an $\mathrm{H}_{2} / \mathrm{C}_{3} \mathrm{H}_{8}$ separation factor of 127 were observed for equimolar $\mathrm{H}_{2} / \mathrm{C}_{3} \mathrm{H}_{8}$ mixture separation at $573 \mathrm{~K}$. Steam stability was further demonstrated with no apparent performance change after testing with an $\mathrm{H}_{2} / \mathrm{CH}_{4}$ mixture containing $3 \mathrm{~mol} \%$ steam at $473 \mathrm{~K}$ for $24 \mathrm{~h}$.

Huang et al. reported a seeding-free synthesis strategy for LTA membrane preparation by introducing enough functional groups ready to combine with zeolite crystals [115]. As shown in Figure 9, this was achieved by functionalizing the support with 3-chloropropyltrimethoxysilane (CPTMS) through a condensation reaction with the hydroxyl group on the support surface. The chloride tail would then react with zeolite to anchor zeolite on the substrate surface during hydrothermal synthesis and further grow to a continuous membrane. The versatility of this synthesis strategy was demonstrated through successful application of various porous supports, such as $\mathrm{Al}_{2} \mathrm{O}_{3}$ disks and tubes and $\mathrm{TiO}_{2}$ disks, as well as dense supports, such as stainless steel, PTFE and glass disks. The $\alpha-\mathrm{Al}_{2} \mathrm{O}_{3}$ disk-supported membrane was further tested for single- and mixture-gas separations at $293 \mathrm{~K}$. The membrane demonstrated an $\mathrm{H}_{2}$ permeance of $1.74 \times 10^{-7} \mathrm{~mol} \cdot \mathrm{m}^{-2} \cdot \mathrm{Pa}^{-1} \cdot \mathrm{s}^{-1}$ and an $\mathrm{H}_{2} / \mathrm{C}_{3} \mathrm{H}_{6}$ separation factor of 36.8, which was much higher than Knudsen diffusion selectivity of 4.58 . The $\mathrm{H}_{2} / \mathrm{C}_{3} \mathrm{H}_{8}$ ideal selectivity was only 23.8 , which was appreciably lower than that of their AlPO form LTA membrane [16]. The Huang group also demonstrated that post-synthesis treatment could be used to enhance membrane performance [164]. The NaA membrane was in situ synthesized on a 3-aminopropyltriethoxysilane (APTES)-treated support. Silver exchange was then conducted by soaking the membrane in $0.05 \mathrm{~mol} / \mathrm{L} \mathrm{AgNO}_{3}$ ethanol solution in a Teflon-lined autoclave for $4 \mathrm{~h}$ at $323 \mathrm{~K}$. The membrane was carefully protected with nitrogen during processing to avoid contact with oxygen. The $\mathrm{H}_{2} / \mathrm{C}_{3} \mathrm{H}_{8}$ ideal selectivity increased from 19.4 to 283.9 after silver exchange to replace $\mathrm{Na}^{+}$with $\mathrm{Ag}^{+}$. The change was because $\mathrm{Ag}^{+}$is larger than $\mathrm{Na}^{+}$ and reduces the effective zeolitic pore opening. The membrane also demonstrated an $\mathrm{H}_{2}$ permeance of $1.6 \times 10^{-7} \mathrm{~mol} \cdot \mathrm{m}^{-2} \cdot \mathrm{Pa}^{-1} \cdot \mathrm{s}^{-1}$ and an $\mathrm{H}_{2} / \mathrm{C}_{3} \mathrm{H}_{8}$ separation factor of 120.8 at $323 \mathrm{~K}$ and 2 bar pressure difference for $\mathrm{H}_{2} / \mathrm{C}_{3} \mathrm{H}_{8}$ equimolar mixture separation.

a

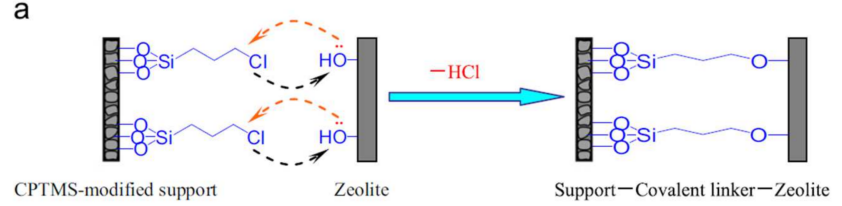

b

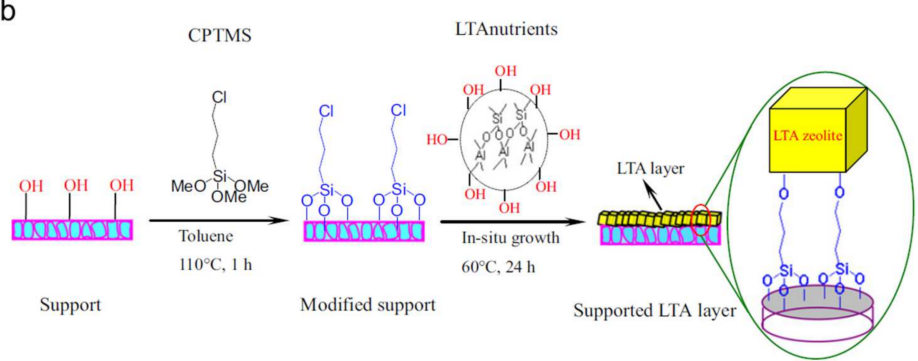

Figure 9. Scheme of the formation of covalent linkers between the support and zeolites (a) and growth of a zeolite LTA membrane layer on CPTMS-functionalized support by in situ anchoring of LTA nutrients during synthesis (b). Reprinted from Huang et al. with permission [115].

A unique membrane synthesis method and gas separation performance was reported by Sen et al. [101] (M Sen, N Das-2018-Ultrasonics-Sonochemistry-Development of LTA zeolite membrane from clay by sonication-assisted method). An indigenous clay- $\mathrm{Al}_{2} \mathrm{O}_{3}$ tube was used as support for membrane synthesis. The substrate was modified by cationic polymer PolyDADMAC $\left(0.5 \mathrm{wt} \%\right.$ in $20 \mathrm{~mL}$ of $\left.\mathrm{H}_{2} \mathrm{O}\right)$ and dried at $333 \mathrm{~K}$ for $30 \mathrm{~min}$, leading to DADMAC polycations adsorbed on the clay-alumina support surface. Then, it was 
dipped in a 3\% zeolite seed suspension. The authors used montmorillonite clay as precursor material for the $\mathrm{Si}$ and $\mathrm{Al}$ source. The molar composition of the sol for zeolite crystal and membrane synthesis was $50 \mathrm{Na}_{2} \mathrm{O}: 1 \mathrm{Al}_{2} \mathrm{O}_{3}: 2.5 \mathrm{SiO}_{2}: 1000 \mathrm{H}_{2} \mathrm{O}$. The seeded supports were placed vertically in the ultrasonically irradiated solution and kept for 15 days aging in a reaction mixture for membrane synthesis. The membrane demonstrated good selectivity for $\mathrm{H}_{2} / \mathrm{CO}_{2}(\sim 15)$ and $\mathrm{CO}_{2} / \mathrm{CH}_{4}(\sim 20)$ at $303 \mathrm{~K}$. Moreover, the membrane had an $\mathrm{H}_{2}$ permeance of over $2 \times 10^{-6} \mathrm{~mol} \cdot \mathrm{m}^{-2} \cdot \mathrm{Pa}^{-1} \cdot \mathrm{s}^{-1}$, which was much higher than that reported in other reports for good-quality LTA-type zeolite membranes. The high $\mathrm{CO}_{2} / \mathrm{CH}_{4}$ separation factor also did not match the $\mathrm{CO}_{2} / \mathrm{CH}_{4}$ selectivity reported by Huang et al. It is worth noting that the zeolite membrane morphology and XRD patterns did not fully match with typical NaA zeolite. Overall, the separation performance was attractive, and the membrane synthesis and permeation phenomena should be further explored to reveal what led to the impressive separation performance.

\subsection{AEI}

All reported AEI membranes are in aluminophosphate form, i.e., AlPO-18. The zeolite framework is formed by $\mathrm{AlO}_{4}{ }^{-}$and $\mathrm{PO}_{4}{ }^{+}$tetrahedrons. The membrane demonstrated good potential for $\mathrm{CO}_{2} / \mathrm{CH}_{4}, \mathrm{CO}_{2} / \mathrm{N}_{2}$ and $\mathrm{N}_{2} / \mathrm{CH}_{4}$ separations. TEAOH was commonly used as a structure-directing agent for crystal and membrane synthesis, with a few exceptions. Representative synthesis conditions and separation performance are summarized in Table 5. Carreon et al. first reported a high-quality AlPO-18 membrane with a $\mathrm{CO}_{2} / \mathrm{CH}_{4}$ separation factor of 60 and a $\mathrm{CO}_{2}$ permeance of $0.66 \times 10^{-7} \mathrm{~mol} \cdot \mathrm{m}^{-2} \cdot \mathrm{Pa}^{-1} \cdot \mathrm{s}^{-1}$ [102]. The membrane was synthesized by rub coating the inner side of the stainless-steel tube with AlPO-18 seeds. Hydrothermal synthesis was then conducted at $473 \mathrm{~K}$ for $72 \mathrm{~h}$. Twostep calcination was used, with the first step at $573 \mathrm{~K}$ for $6 \mathrm{~h}$ and then $673 \mathrm{~K}$ for $10 \mathrm{~h}$. Wang et al. used a $1.0 \mathrm{Al}_{2} \mathrm{O}_{3}: 1.0 \mathrm{P}_{2} \mathrm{O}_{5}$ molar ratio in the precursor and tried different TEAOH and water contents [14]. Their optimized precursor solution has a molar ratio of $1.0 \mathrm{Al}_{2} \mathrm{O}_{3}: 1.0 \mathrm{P}_{2} \mathrm{O}_{5}: 2 \mathrm{TEAOH}: 160 \mathrm{H}_{2} \mathrm{O}$. The synthesis duration was reduced to $14 \mathrm{~h}$. The resulting zeolite film thickness was only slightly thinner $(\sim 8 \mu \mathrm{m})$ but demonstrated about 10 times higher $\mathrm{CO}_{2}$ permeance and excellent $\mathrm{CO}_{2} / \mathrm{CH}_{4}$ selectivity. Zong et al. achieved AlPO-18 membranes with $\mathrm{N}_{2}$ permeance as high as $10.7 \times 10^{-7} \mathrm{~mol} \cdot \mathrm{m}^{-2} \cdot \mathrm{Pa}^{-1} \cdot \mathrm{s}^{-1}$ and good $\mathrm{N}_{2} / \mathrm{CH}_{4}$ selectivity (up to 4.6), which is much higher than the Knudsen diffusion selectivity of 0.76 [141]. Wu et al. used N, N-diisopropylethylamine (DIPEA) as the OSDA instead of TEAOH [104]. They studied the influence of DIPEA concentration on membrane synthesis with a precursor composition of $1.0 \mathrm{Al}_{2} \mathrm{O}_{3}: 1.0 \mathrm{P}_{2} \mathrm{O}_{5}: x D I P E A: 120 \mathrm{H}_{2} \mathrm{O}$. When $x$ was 1 and 1.2, an AFI impurity phase was observed when synthesis duration was increased from 36 to $48 \mathrm{~h}$. When $\mathrm{x}$ was increased to $1.8,48 \mathrm{~h}$ of synthesis still resulted in pure AEI film. The best membrane had a $\mathrm{CO}_{2}$ permeance of $2.82 \times 10^{-6} \mathrm{~mol} \cdot \mathrm{m}^{-2} \cdot \mathrm{Pa}^{-1} \cdot \mathrm{s}^{-1}$ and good $\mathrm{CO}_{2} / \mathrm{CH}_{4}$ ideal selectivity (53.8). Reproducibility is still an issue for synthesis, as two of the four membranes were leaking, and the third membrane only had a $\mathrm{CO}_{2} / \mathrm{CH}_{4}$ ideal selectivity of 8.49. Wang et al. achieved the highest $\mathrm{CO}_{2}$ permeance $\left(3.6 \times 10^{-6} \mathrm{~mol} \cdot \mathrm{m}^{-2} \cdot \mathrm{Pa}^{-1} \cdot \mathrm{s}^{-1}\right)$, with an excellent $\mathrm{CO}_{2} / \mathrm{CH}_{4}$ separation factor (91.5) performance with AlPO-18 membrane [30]. Their membrane had oriented film with (002) direction in the bottom layer and (110) direction in the top layer, as shown in Figure 10. Such oriented film was achieved within single-hydrothermal synthesis through three changes for the synthesis, compared to their previous work. First, they used nanosheet seeds with a higher aspect ratio. Second, asymmetric alumina supports were used instead of symmetric supports to prevent growth of AlPO-18 crystals inside the support pores. Lastly, membrane synthesis parameters, including template concentration, synthesis temperature and time were optimized in this work. 
Table 5. AEI-type zeolite membrane synthesis conditions and corresponding separation performance.

\begin{tabular}{|c|c|c|c|c|c|c|c|}
\hline Synthesis Conditions & Substrate & $\delta, \mathrm{um}$ & $P_{\text {feed }}$ and $T$ & A/B Gas & $\begin{array}{c}\mathbf{P}_{\mathrm{m}, \mathrm{A}}, \times 10^{-7} \\
\mathbf{m o l} \cdot \mathrm{m}^{-2} \cdot \mathbf{P a}^{-1} \cdot \mathrm{s}^{-1}\end{array}$ & $\alpha_{\mathrm{A} / \mathrm{B}}$ & Ref. \\
\hline $\begin{array}{c}1 \mathrm{Al}_{2} \mathrm{O}_{3}: 3.15 \mathrm{P}_{2} \mathrm{O}_{5}: 6.3 \mathrm{TEAOH}: 185 \mathrm{H}_{2} \mathrm{O}, 473 \mathrm{~K} \\
72 \mathrm{~h} \text { by } 2 \text { nd growth }\end{array}$ & Stainless steel tube & $\sim 10$ & $0.24 \mathrm{MPa}, 295 \mathrm{~K}$ & $\mathrm{CO}_{2} / \mathrm{CH}_{4}$ & 0.66 & 60 & [102] \\
\hline $\begin{array}{c}1.0 \mathrm{Al}_{2} \mathrm{O}_{3}: 1.0 \mathrm{P}_{2} \mathrm{O}_{5}: 2 \mathrm{TEAOH}: 160 \mathrm{H}_{2} \mathrm{O}, 488 \mathrm{~K} \\
14 \mathrm{~h} \text { by } 2 \text { nd growth }\end{array}$ & $\alpha-\mathrm{Al}_{2} \mathrm{O}_{3}$ tube & $\sim 8$ & $0.3 \mathrm{MPa}, 298 \mathrm{~K}$ & $\mathrm{CO}_{2} / \mathrm{CH}_{4}$ & 6.5 & 220 & [14] \\
\hline $\begin{array}{c}1.0 \mathrm{Al}_{2} \mathrm{O}_{3}: 1 \mathrm{P}_{2} \mathrm{O}_{5}: 1.8 \mathrm{TEAOH}: 120 \mathrm{H}_{2} \mathrm{O}, 488 \mathrm{~K} \\
10 \mathrm{~h} \text { by } 2 \text { nd growth }\end{array}$ & $\alpha-\mathrm{Al}_{2} \mathrm{O}_{3}$ tube & $\sim 2.5$ & $0.223 \mathrm{MPa}, \mathrm{RT}$ & $\mathrm{N}_{2} / \mathrm{CH}_{4}$ & 10.7 & 3.8 & [141] \\
\hline $\begin{array}{c}1.0 \mathrm{Al}_{2} \mathrm{O}_{3}: 1.0 \mathrm{P}_{2} \mathrm{O}_{5}: 1.8 \mathrm{DIPEA}: 120 \mathrm{H}_{2} \mathrm{O}, 478 \mathrm{~K} \\
48 \mathrm{~h} \text { by } 2 \text { nd growth }\end{array}$ & $\alpha-\mathrm{Al}_{2} \mathrm{O}_{3}$ tube & $\sim 4.5$ & $0.11 \mathrm{MPa}, 308 \mathrm{~K}$ & $\mathrm{CO}_{2} / \mathrm{CH}_{4}{ }^{*}$ & 28.2 & 53.8 & [104] \\
\hline $\begin{array}{c}1.0 \mathrm{Al}_{2} \mathrm{O}_{3}: 1.0 \mathrm{P}_{2} \mathrm{O}_{5}: 1.34 \text { TEAOH: } 200 \mathrm{H}_{2} \mathrm{O} \\
423 \mathrm{~K} \text { for } 48 \mathrm{~h}\end{array}$ & $\alpha-\mathrm{Al}_{2} \mathrm{O}_{3}$ tube & $\sim 4$ & $0.3 \mathrm{MPa}, 298 \mathrm{~K}$ & $\mathrm{CO}_{2} / \mathrm{CH}_{4}$ & 36 & 91.5 & [30] \\
\hline
\end{tabular}

* denotes results from single gas permeation tests.

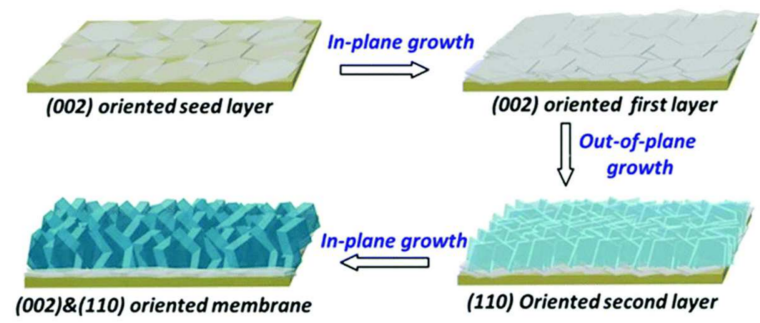

Figure 10. Schematic diagram for the growth of the (110) and (002)-oriented AlPO-18 membrane by single-hydrothermal synthesis. Reprinted from Wang et al. with permission [30].

\subsection{ANA, ERI, GIS and RHO}

The synthesis conditions and corresponding separation performance of other smallpore zeolite membranes are summarized in Table 6. Anbia and coworkers reported the synthesis of an analcime (ANA type) zeolite membrane [165]. However, there was no report on any separation performance to help judge the membrane quality. They tried synthesizing ANA zeolite crystals with and without OSDA, here as TMAOH. The influence of the amount of water, $\mathrm{Na}_{2} \mathrm{O}$ and $\mathrm{SiO}_{2}$ in the precursor was studied, as well as and synthesis duration. An optimum crystal synthesis condition was determined and also used for secondary growth of the membrane. No Si/Al ratio in the membrane was directly reported. From EDX spectra, Al content was quite high just like many other zeolite membranes synthesized by the template-free method, despite the high $\mathrm{Si} / \mathrm{Al}$ ratio in the precursor.

Table 6. ANA, ERI, GIS and RHO-type zeolite membrane synthesis conditions and corresponding separation performance.

\begin{tabular}{|c|c|c|c|c|c|c|c|c|}
\hline Type & Synthesis Conditions & Support & $\delta, \mathrm{um}$ & $P_{\text {feed }}$ and $T$ & A/B Gas & $\begin{array}{l}\mathrm{P}_{\mathrm{m}, \mathrm{A}}, \times 10^{-7} \\
\mathbf{m o l} \cdot \mathrm{m}^{-2} \cdot \mathrm{Pa}^{-1} \cdot \mathrm{s}^{-1}\end{array}$ & $\alpha_{\mathrm{A} / \mathrm{B}}$ & Ref. \\
\hline ANA & $\begin{array}{c}50 \mathrm{SiO}_{2}: 1 \mathrm{Al}_{2} \mathrm{O}_{3}: 33 \mathrm{Na}_{2} \mathrm{O}: 4800 \mathrm{H}_{2} \mathrm{O}, 453 \mathrm{~K} \\
\text { for } 72 \mathrm{~h} \text { by } 2 \text { nd growth }\end{array}$ & $\alpha-\mathrm{Al}_{2} \mathrm{O}_{3}$ disk & NA & NA & NA & NA & NA & [165] \\
\hline ERI & $\begin{array}{l}1.0 \mathrm{Al}_{2} \mathrm{O}_{3}: 1.0 \mathrm{P}_{2} \mathrm{O}_{5}: 1.0 \text { cyclohexylamine } \\
: 220 \mathrm{H}_{2} \mathrm{O}, 473 \mathrm{~K} \text { for } 90 \mathrm{~h} \text { by } 2 \text { nd growth }\end{array}$ & Mullite tube & $\sim 12$ & $0.3 \mathrm{MPa}, 298 \mathrm{~K}$ & $\mathrm{CO}_{2} / \mathrm{CH}_{4}$ & 11 & 53 & [106] \\
\hline GIS & $\begin{array}{l}1 \mathrm{SiO}_{2}: 0.1 \mathrm{Al}_{2} \mathrm{O}_{3}: 0.35 \mathrm{Na}_{2} \mathrm{O}: 80 \mathrm{H}_{2} \mathrm{O}, 373 \mathrm{~K} \\
\text { for } 12 \mathrm{~h} \text { by two-time synthesis }\end{array}$ & $\alpha-\mathrm{Al}_{2} \mathrm{O}_{3}$ disk & $\sim 15$ & $298 \mathrm{~K}$ & $\mathrm{H}_{2} / \mathrm{SF}^{*} *$ & 5.71 & 102 & [166] \\
\hline $\mathrm{RHO}$ & $\begin{array}{l}10.8 \mathrm{SiO}_{2}: 1 \mathrm{Al}_{2} \mathrm{O}_{3}: 3 \mathrm{Na}_{2} \mathrm{O}: 0.4 \mathrm{Cs}_{2} \mathrm{O}: 110 \mathrm{H}_{2} \mathrm{O} \\
\text { :1HF, } 383 \mathrm{~K} \text { for } 6 \text { days by } 2 \text { nd growth }\end{array}$ & $\alpha-\mathrm{Al}_{2} \mathrm{O}_{3}$ tube & $1 \sim 2$ & $0.1 \mathrm{MPa}, 308 \mathrm{~K}$ & $\mathrm{CO}_{2} / \mathrm{CH}_{4} *$ & 0.5 & 6.8 & [105] \\
\hline
\end{tabular}

* denotes results from single gas permeation tests.

The first ERI-type zeolite membrane was reported by Zhong et al. [106] The membrane was prepared by using zeolite $\mathrm{T}$ crystals as silica precursor to prepare pure and submicron SAPO-17 crystal seeds. The uncalcined seeds were then rub-coated on the outer surface of ceramic substrates. The membrane synthesis gel had a molar composition of $1.0 \mathrm{Al}_{2} \mathrm{O}_{3}$ : $1.0 \mathrm{P}_{2} \mathrm{O}_{5}: 1.0$ cyclohexylamine:220 $\mathrm{H}_{2} \mathrm{O}$. No silica source was added to the precursor gel. Synthesis was conducted at $473 \mathrm{~K}$ for $90 \mathrm{~h}$. The authors tried both mullite and $\alpha$ alumina tubular substrates. The membrane on mullite support was denoted as an SAPO-17 membrane, with an $\mathrm{Si} / \mathrm{Al} / \mathrm{P}$ molar ratio of $1 / 14 / 17$ by EDX. The significant amount of 
$\mathrm{Si}$ was mainly attributed to silicon from the mullite support $(\mathrm{Si} / \mathrm{Al}=0.3)$. In contrast, the membrane on alumina support did not show appreciable Si content by EDX and was noted as an AlPO-17 membrane. The SAPO-17 membranes demonstrated appreciably higher permeance and selectivity compared to AlPO-17 membranes. Despite the thick membrane $(\sim 12 \mu \mathrm{m})$, the high $\mathrm{CO}_{2}$ permeance, together with good $\mathrm{CO}_{2} / \mathrm{CH}_{4}$ selectivity, indicates the good potential of the ERI-type zeolite membrane.

P-type zeolite was first reported by Dong and Lin through template-free synthesis [166]. They used a homemade $\alpha-\mathrm{Al}_{2} \mathrm{O}_{3}$ disk as support. The precursor gel was composed of $1.64 \mathrm{~g}$ of $\mathrm{NaAlO}_{2}, 12.2 \mathrm{~g}$ of $\mathrm{Na}_{2} \mathrm{SiO}_{3}, 2.4 \mathrm{~g}$ of $\mathrm{NaOH}$ and $143.2 \mathrm{~g}$ of $\mathrm{H}_{2} \mathrm{O}$. The gel was aged for $20 \mathrm{~h}$ at room temperature under vigorous stirring. The substrate was lined vertically, partially vertically and face-up for membrane synthesis. Hydrothermal synthesis was conducted at $373 \mathrm{~K}$ for $12 \mathrm{~h}$. After one in situ synthesis, the membrane was still quite defective. A second synthesis was typically required. The best membrane demonstrated an $\mathrm{H}_{2} / \mathrm{SF}_{6}$ ideal selectivity of 102 , which was much higher than the selectivity of 8.54 by Knudsen diffusion mechanism. This indicates good membrane quality. P zeolite has the problem of a phase transition from the cubic phase to the tetragonal phase. There was a decrease in the volume of unit cells, which might result in crack formation accompanying the phase transformation. Despite the reduced membrane thickness and formation of crystal powder scaling on the membrane surface after heat treatments at 338 and $373 \mathrm{~K}$, there was no dramatic change in membrane permeances. This indicates that the membrane quality was not significantly affected by the phase transition.

Liu et al. reported the synthesis of an RHO zeolite membrane for the first time [105]. The membrane was synthesized by the template-free method. The seed crystal was synthesized at $373 \mathrm{~K}$ for 4 days with a precursor gel composition of $10.8 \mathrm{SiO}_{2}: 1 \mathrm{Al}_{2} \mathrm{O}_{3}: 3 \mathrm{Na}_{2} \mathrm{O}: 0.4 \mathrm{Cs}_{2} \mathrm{O}$ : $110 \mathrm{H}_{2} \mathrm{O}$. The resulting crystal size was about $0.8 \mu \mathrm{m}$. The seed was rub-coated on the outer surface of the $\alpha-\mathrm{Al}_{2} \mathrm{O}_{3}$ tubular substrate. Hydrothermal synthesis was conducted with a precursor gel solution of $10.8 \mathrm{SiO}_{2}: 1 \mathrm{Al}_{2} \mathrm{O}_{3}: 3 \mathrm{Na}_{2} \mathrm{O}: 0.4 \mathrm{Cs}_{2} \mathrm{O}: 110 \mathrm{H}_{2} \mathrm{O}$ :

$1 \mathrm{HF}$. HF was added in order to improve membrane quality. The membrane demonstrated a $\mathrm{CO}_{2} / \mathrm{CH}_{4}$ ideal selectivity of 6.8 , which is significantly higher than the Knudsen diffusion selectivity of 0.60 . This indicates the membrane is free from major defects. The membrane was also tested for dehydration of $10 / 90 \mathrm{wt} . \%$ water/organics at $348 \mathrm{~K}$. The membrane showed a water flux of $0.76 \mathrm{~kg} \cdot \mathrm{m}^{-2} \cdot \mathrm{h}^{-1}$ and a water/ethanol separation factor of 473 .

\section{Conclusions}

Within the last three decades, there have been remarkable advances in small-pore zeolite membranes. They have demonstrated very attractive gas separation performance for various gas pairs, such as $\mathrm{CO}_{2} / \mathrm{CH}_{4}, \mathrm{H}_{2} / \mathrm{CO}_{2}, \mathrm{~N}_{2} / \mathrm{CH}_{4}$ and $\mathrm{Xe}$ from $\mathrm{Kr}$ or $\mathrm{CO}_{2}$. It is thrilling to see joint efforts from academia and industry for continuous performance improvement, more realistic separation tests and development of large-scale membrane modules. However, there is still no major industrial gas separation application for zeolite membranes. The following observations, challenges and future work for small-pore zeolite membrane development have been identified:

- CHA-type zeolite membranes demonstrated the most attractive separation performance for most studied applications. Two major contributing factors: CHA-type zeolite membranes (1) are more mature, with 20 years of development, and (2) have three-dimensional channels and a suitable pore size.

- $\quad$ AEI-type zeolite membranes have similar potential as CHA zeolite membranes based on their structural similarity and demonstrated separation performance. Nonionic LTA-type zeolite membranes might find applications other than those commonly studied because of a slightly larger pore size.

- Small-pore zeolite membranes demonstrated more attractive separation performance towards $\mathrm{CO}_{2} / \mathrm{CH}_{4}, \mathrm{~N}_{2} / \mathrm{CH}_{4}$ and Xe separation applications compared to polymer 
membranes. These areas have better chances for industrial implementation of zeolite membranes.

- Small-pore zeolite membranes have contributed to higher reactant conversion and product yield when used in membrane reactors. The high chemical and thermal stability, together with good separation performance, could make zeolite membranes great candidates in applications involving harsh operating conditions, such as acidic and high-temperature environments.

- Preventing zeolite growth inside porous substrates and reducing membrane thickness are effective strategies for improving membrane permeance. Simplifying highperformance membrane fabrication processes is another important aspect for reduced fabrication cost.

- Large-scale membrane synthesis with high-aspect-ratio substrates, such as multichannel monoliths, are attractive for efficient synthesis. The development of cheap, high-quality supports for zeolite membranes is crucial for reducing zeolite membrane cost.

- It is important to conduct more membrane tests under close-to-realistic operating conditions, such as complex/real feed mixture and high operating pressure, to reveal real-world performance for better assessment of membrane potential.

Author Contributions: Conceptualization, S.Y.; data collection, Z.C. and N.D.A.; writing-original draft preparation, Z.C. and S.Y.; writing-review and editing, Z.C. and S.Y. All authors have read and agreed to the published version of the manuscript.

Funding: This research received no external funding.

Data Availability Statement: All data are supplied in the manuscript.

Acknowledgments: We acknowledge the support of Cleveland State University (CSU) for Faculty Start-Up Funds.

Conflicts of Interest: The authors declare no conflict of interest.

\section{References}

1. Jeon, M.Y.; Kim, D.; Kumar, P.; Lee, P.S.; Rangnekar, N.; Bai, P.; Shete, M.; Elyassi, B.; Lee, H.S.; Narasimharao, K.; et al. Ultraselective high-flux membranes from directly synthesized zeolite nanosheets. Nature 2017, 543, 690-694. [CrossRef] [PubMed]

2. Min, B.; Yang, S.; Korde, A.; Kwon, Y.H.; Jones, C.W.; Nair, S. Continuous Zeolite MFI Membranes Fabricated from 2D MFI Nanosheets on Ceramic Hollow Fibers. Angew. Chem. Int. Ed. 2019, 58, 8201-8205. [CrossRef] [PubMed]

3. Yu, L.; Nobandegani, M.S.; Hedlund, J. Industrially relevant $\mathrm{CHA}$ membranes for $\mathrm{CO}_{2} / \mathrm{CH}_{4}$ separation. J. Membr. Sci. 2022, 641, 119888. [CrossRef]

4. Baerlocher, C.; McCusker, L.B.; Olson, D.H. Atlas of Zeolite Framework Types-6th Edition; Elsevier Science: Amsterdam, The Netherlands, 2007.

5. Barrer, R.M. Flow into and through zeolite beds and compacts. Langmuir 1987, 3, 309-315. [CrossRef]

6. Barrer, R.M. Porous crystal membranes. J. Chem. Soc. Faraday Trans. 1990, 86, 1123-1130. [CrossRef]

7. Tavolaro, A.; Drioli, E. Zeolite membranes. Adv. Mater. 1999, 11, 975-996. [CrossRef]

8. Caro, J.; Noack, M. Zeolite membranes-Recent developments and progress. Microporous Mesoporous Mater. 2008, 115, 215-233. [CrossRef]

9. Caro, J.; Noack, M.; Kölsch, P.; Schäfer, R. Zeolite membranes-state of their development and perspective. Microporous Mesoporous Mater. 2000, 38, 3-24. [CrossRef]

10. Feng, C.; Khulbe, K.; Matsuura, T.; Farnood, R.; Ismail, A. Recent Progress in Zeolite/Zeotype Membranes. J. Membr. Sci. Res. 2015, 1, 49-72. [CrossRef]

11. Rangnekar, N.; Mittal, N.; Elyassi, B.; Caro, J.; Tsapatsis, M. Zeolite membranes-A review and comparison with MOFs. Chem. Soc. Rev. 2015, 44, 7128-7154. [CrossRef]

12. Moliner, M.; Martínez, C.; Corma, A. Synthesis Strategies for Preparing Useful Small Pore Zeolites and Zeotypes for Gas Separations and Catalysis. Chem. Mater. 2013, 26, 246-258. [CrossRef]

13. Zhou, J.; Gao, F.; Sun, K.; Jin, X.; Zhang, Y.; Liu, B.; Zhou, R. Green Synthesis of Highly $\mathrm{CO}_{2}$-Selective CHA Zeolite Membranes in All-Silica and Fluoride-Free Solution for CO2/CH4 Separations. Energy Fuels 2020, 34, 11307-11314. [CrossRef]

14. Wang, B.; Hu, N.; Wang, H.; Zheng, Y.; Zhou, R. Improved AlPO-18 membranes for light gas separation. J. Mater. Chem. A 2015, 3, 12205-12212. [CrossRef] 
15. Wang, B.; Zheng, Y.; Zhang, J.; Zhang, W.; Zhang, F.; Xing, W.; Zhou, R. Separation of light gas mixtures using zeolite SSZ-13 membranes. Microporous Mesoporous Mater. 2018, 275, 191-199. [CrossRef]

16. Huang, A.; Liang, F.; Steinbach, F.; Gesing, T.M.; Caro, J. Neutral and Cation-Free LTA-Type Aluminophosphate (AlPO4) Molecular Sieve Membrane with High Hydrogen Permselectivity. J. Am. Chem. Soc. 2010, 132, 2140-2141. [CrossRef]

17. Wang, Y.; Rong, H.; Sun, L.; Zhang, P.; Yang, Y.; Jiang, L.; Wu, S.; Zhu, G.; Zou, X. Fabrication and evaluation of effective zeolite membranes for water desalination. Desalination 2021, 504, 114974. [CrossRef]

18. Bowen, T.C.; Noble, R.D.; Falconer, J.L. Fundamentals and applications of pervaporation through zeolite membranes. J. Membr. Sci. 2004, 245, 1-33. [CrossRef]

19. Wee, S.-L.; Tye, C.-T.; Bhatia, S. Membrane separation process-Pervaporation through zeolite membrane. Sep. Purif. Technol. 2008, 63, 500-516. [CrossRef]

20. Bastani, D.; Esmaeili, N.; Asadollahi, M. Polymeric mixed matrix membranes containing zeolites as a filler for gas separation applications: A review. J. Ind. Eng. Chem. 2013, 19, 375-393. [CrossRef]

21. Xu, J.; Haw, K.-G.; Li, Z.; Pati, S.; Wang, Z.; Kawi, S. A mini-review on recent developments in SAPO-34 zeolite membranes and membrane reactors. React. Chem. Eng. 2020, 6, 52-66. [CrossRef]

22. Wang, L.; Zhang, C.; Gao, X.; Peng, L.; Jiang, J.; Gu, X. Preparation of defect-free DDR zeolite membranes by eliminating template with ozone at low temperature. J. Membr. Sci. 2017, 539, 152-160. [CrossRef]

23. Yang, S.; Kwon, Y.H.; Koh, D.-Y.; Min, B.; Liu, Y.; Nair, S. Highly Selective SSZ-13 Zeolite Hollow Fiber Membranes by Ultraviolet Activation at Near-Ambient Temperature. Chemnanomat 2018, 5, 61-67. [CrossRef]

24. Robeson, L.M. Correlation of separation factor versus permeability for polymeric membranes. J. Membr. Sci. 1991, 62, 165-185. [CrossRef]

25. Robeson, L.M. The upper bound revisited. J. Membr. Sci. 2008, 320, 390-400. [CrossRef]

26. Koros, W.J.; Zhang, C. Materials for next-generation molecularly selective synthetic membranes. Nat. Mater. 2017, 16, 289-297. [CrossRef]

27. Robeson, L.M.; Dose, M.E.; Freeman, B.D.; Paul, D.R. Analysis of the transport properties of thermally rearranged (TR) polymers and polymers of intrinsic microporosity (PIM) relative to upper bound performance. J. Membr. Sci. 2017, 525, 18-24. [CrossRef]

28. Comesaña-Gándara, B.; Chen, J.; Bezzu, C.G.; Carta, M.; Rose, I.; Ferrari, M.-C.; Esposito, E.; Fuoco, A.; Jansen, J.C.; McKeown, N.B. Redefining the Robeson upper bounds for $\mathrm{CO}_{2} / \mathrm{CH}_{4}$ and $\mathrm{CO}_{2} / \mathrm{N}_{2}$ separations using a series of ultrapermeable benzotriptycenebased polymers of intrinsic microporosity. Energy Environ. Sci. 2019, 12, 2733-2740. [CrossRef]

29. Wu, A.X.; Drayton, J.A.; Smith, Z.P. The perfluoropolymer upper bound. AIChE J. 2019, 65, e16700. [CrossRef]

30. Wang, B.; Gao, F.; Zhang, F.; Xing, W.; Zhou, R. Highly permeable and oriented AlPO-18 membranes prepared using directly synthesized nanosheets for $\mathrm{CO}_{2} / \mathrm{CH}_{4}$ separation. J. Mater. Chem. A 2019, 7, 13164-13172. [CrossRef]

31. Kida, K.; Maeta, Y.; Yogo, K. Pure silica CHA-type zeolite membranes for dry and humidified CO2/CH4 mixtures separation. Sep. Purif. Technol. 2018, 197, 116-121. [CrossRef]

32. Yu, L.; Nobandegani, M.S.; Holmgren, A.; Hedlund, J. Highly permeable and selective tubular zeolite CHA membranes. J. Membr. Sci. 2019, 588, 117224. [CrossRef]

33. Wu, T.; Wang, B.; Lu, Z.-H.; Zhou, R.; Chen, X. Alumina-supported AlPO-18 membranes for CO2/CH4 separation. J. Membr. Sci. 2014, 471, 338-346. [CrossRef]

34. Poshusta, J.C.; Noble, R.D.; Falconer, J.L. Characterization of SAPO-34 membranes by water adsorption. J. Membr. Sci. 2001, 186, 25-40. [CrossRef]

35. Li, S.; Fan, C.Q. High-Flux SAPO-34 Membrane for CO2/N2 Separation. Ind. Eng. Chem. Res. 2010, 49, 4399-4404. [CrossRef]

36. Mu, Y.; Chen, H.; Xiang, H.; Lan, L.; Shao, Y.; Fan, X.; Hardacre, C. Defects-healing of SAPO-34 membrane by post-synthesis modification using organosilica for selective $\mathrm{CO}_{2}$ separation. J. Membr. Sci. 2019, 575, 80-88. [CrossRef]

37. Mirfendereski, S.M. RETRACTED: Development of a multi-step hybrid method to synthesize highly-permeable and well-oriented SAPO-34 membranes for $\mathrm{CO}_{2}$ removal applications. Chem. Eng. Sci. 2019, 208, 115157. [CrossRef]

38. Bai, L.; Chang, N.; Li, M.; Wang, Y.; Nan, G.; Zhang, Y.; Hu, D.; Zeng, G.; Wei, W. Ultrafast synthesis of thin SAPO-34 zeolite membrane by oil-bath heating. Microporous Mesoporous Mater. 2017, 241, 392-399. [CrossRef]

39. Chen, Y.; Zhang, Y.; Zhang, C.; Jiang, J.; Gu, X. Fabrication of high-flux SAPO-34 membrane on $\alpha-\mathrm{Al}_{2} \mathrm{O}_{3}$ four-channel hollow fibers for $\mathrm{CO}_{2}$ capture from $\mathrm{CH}$ 4. J. Co2 Util. 2017, 18, 30-40. [CrossRef]

40. Bing, L.; Wang, G.; Wang, F.; Liu, X.; Zhang, B. Preparation of a preferentially oriented SAPO-34 membrane by secondary growth under microwave irradiation. RSC Adv. 2016, 6, 56170-56173. [CrossRef]

41. Li, M.; Zhang, J.; Liu, X.; Wang, Y.; Liu, C.; Hu, D.; Zeng, G.; Zhang, Y.; Wei, W.; Sun, Y. Synthesis of high performance SAPO-34 zeolite membrane by a novel two-step hydrothermal synthesis + dry gel conversion method. Microporous Mesoporous Mater. 2016, 225, 261-271. [CrossRef]

42. Shi, H. Organic template-free synthesis of SAPO-34 molecular sieve membranes for $\mathrm{CO}_{2}-\mathrm{CH}_{4}$ separation. $\mathrm{RSC}$ Adv. 2015, 5, 38330-38333. [CrossRef]

43. Funke, H.H.; Chen, M.Z.; Prakash, A.N.; Falconer, J.L.; Noble, R.D. Separating molecules by size in SAPO-34 membranes. J. Membr. Sci. 2014, 456, 185-191. [CrossRef]

44. Zhou, R.; Ping, E.W.; Funke, H.H.; Falconer, J.L.; Noble, R.D. Improving SAPO-34 membrane synthesis. J. Membr. Sci. 2013, 444, 384-393. [CrossRef] 
45. Ping, E.W.; Zhou, R.; Funke, H.H.; Falconer, J.L.; Noble, R.D. Seeded-gel synthesis of SAPO-34 single channel and monolith membranes, for $\mathrm{CO}_{2} / \mathrm{CH}_{4}$ separations. J. Membr. Sci. 2012, 415-416, 770-775. [CrossRef]

46. Chew, T.L.; Ahmad, A.L.; Bhatia, S. Ba-SAPO-34 membrane synthesized from microwave heating and its performance for CO2/CH4 gas separation. Chem. Eng. J. 2011, 171, 1053-1059. [CrossRef]

47. Venna, S.R.; Carreon, M.A. Amino-Functionalized SAPO-34 Membranes for $\mathrm{CO}_{2} / \mathrm{CH}_{4}$ and $\mathrm{CO}_{2} / \mathrm{N}_{2}$ Separation. Langmuir 2011, 27, 2888-2894. [CrossRef] [PubMed]

48. Aydani, A.; Brunetti, A.; Maghsoudi, H.; Barbieri, G. $\mathrm{CO}_{2}$ separation from binary mixtures of $\mathrm{CH}_{4}, \mathrm{~N}_{2}$, and $\mathrm{H}_{2}$ by using SSZ-13 zeolite membrane. Sep. Purif. Technol. 2020, 256, 117796. [CrossRef]

49. Aydani, A.; Maghsoudi, H.; Brunetti, A.; Barbieri, G. Silica sol gel assisted defect patching of SSZ-13 zeolite membranes for CO2/CH4 separation. Sep. Purif. Technol. 2021, 277, 119518. [CrossRef]

50. Liu, B.; Zhou, R.; Bu, N.; Wang, Q.; Zhong, S.; Wang, B.; Hidetoshi, K. Room-temperature ionic liquids modified zeolite SSZ-13 membranes for $\mathrm{CO}_{2} / \mathrm{CH}_{4}$ separation. J. Membr. Sci. 2017, 524, 12-19. [CrossRef]

51. Liu, H.; Gao, X.; Wang, S.; Hong, Z.; Wang, X.; Gu, X. SSZ-13 zeolite membranes on four-channel $\alpha-\mathrm{Al}_{2} \mathrm{O}_{3}$ hollow fibers for $\mathrm{CO}_{2}$ separation. Sep. Purif. Technol. 2021, 267, 118611. [CrossRef]

52. Maghsoudi, H.; Soltanieh, M. Simultaneous separation of $\mathrm{H}_{2} \mathrm{~S}$ and $\mathrm{CO}_{2}$ from $\mathrm{CH}_{4}$ by a high silica CHA-type zeolite membrane. J. Membr. Sci. 2014, 470, 159-165. [CrossRef]

53. Qiu, H.; Zhang, Y.; Kong, L.; Kong, X.; Tang, X.; Meng, D.; Xu, N.; Wang, M.; Zhang, Y. High performance SSZ-13 membranes prepared at low temperature. J. Membr. Sci. 2020, 603, 118023. [CrossRef]

54. Tang, H.; Bai, L.; Wang, M.; Zhang, Y.; Li, M.; Wang, M.; Kong, L.; Xu, N.; Zhang, Y.; Rao, P. Fast synthesis of thin high silica SSZ-13 zeolite membrane using oil-bath heating. Int. J. Hydrogen Energy 2019, 44, 23107-23119. [CrossRef]

55. Kim, J.; Jang, E.; Hong, S.; Kim, D.; Kim, E.; Ricther, H.; Simon, A.; Choi, N.; Korelskiy, D.; Fouladvand, S.; et al. Microstructural control of a SSZ-13 zeolite film via rapid thermal processing. J. Membr. Sci. 2019, 591, 117342. [CrossRef]

56. Kalipcilar, H.; Bowen, T.C.; Noble, R.D.; Falconer, J.L. Synthesis and Separation Performance of SSZ-13 Zeolite Membranes on Tubular Supports. Chem. Mater. 2002, 14, 3458-3464. [CrossRef]

57. Kosinov, N.; Auffret, C.; Borghuis, G.J.; Sripathi, V.G.; Hensen, E.J. Influence of the Si/Al ratio on the separation properties of SSZ-13 zeolite membranes. J. Membr. Sci. 2015, 484, 140-145. [CrossRef]

58. Kosinov, N.; Auffret, C.; Sripathi, V.G.; Gücüyener, C.; Gascon, J.; Kapteijn, F.; Hensen, E.J. Influence of support morphology on the detemplation and permeation of ZSM-5 and SSZ-13 zeolite membranes. Microporous Mesoporous Mater. 2014, 197, 268-277. [CrossRef]

59. Kosinov, N.; Auffret, C.; Gücüyener, C.; Szyja, B.M.; Gascon, J.; Kapteijn, F.; Hensen, E.J.M. High flux high-silica SSZ-13 membrane for $\mathrm{CO}_{2}$ separation. J. Mater. Chem. A 2014, 2, 13083-13092. [CrossRef]

60. Chisholm, N.O.; Funke, H.H.; Noble, R.D.; Falconer, J.L. Carbon dioxide/alkane separations in a SSZ-13 membrane. J. Membr. Sci. 2018, 568, 17-21. [CrossRef]

61. Hong, S.; Kim, D.; Jeong, Y.; Kim, E.; Jung, J.C.; Choi, N.; Nam, J.; Yip, A.C.K.; Choi, J. Healing of Microdefects in SSZ-13 Membranes via Filling with Dye Molecules and Its Effect on Dry and Wet $\mathrm{CO}_{2}$ Separations. Chem. Mater. 2018, 30, 3346-3358. [CrossRef]

62. Song, S.; Gao, F.; Zhang, Y.; Li, X.; Zhou, M.; Wang, B.; Zhou, R. Preparation of SSZ-13 membranes with enhanced fluxes using asymmetric alumina supports for $\mathrm{N}_{2} / \mathrm{CH}_{4}$ and $\mathrm{CO}_{2} / \mathrm{CH}_{24}$ separations. Sep. Purif. Technol. 2018, 209, 946-954. [CrossRef]

63. Gui, T.; Chen, X.; Zhu, M.; An, X.; Wang, H.; Wu, T.; Zhang, F.; Chen, X.; Kita, H. Gas Separation Performance of SSZ-13 Zeolite Membranes on Different Supports. Energy Fuels 2021, 35, 14852-14859. [CrossRef]

64. Kong, X.; Qiu, H.; Meng, D.; Tang, X.; Yang, S.; Guo, W.; Zhang, Y.; Kong, L.; Zhang, Y.; Zhang, Z. Reproducible synthesis of all-silica CHA zeolite membranes in a homogeneous mother liquor. Sep. Purif. Technol. 2021, 274, 119104. [CrossRef]

65. Li, X.; Wang, Y.; Wu, T.; Song, S.; Wang, B.; Zhong, S.; Zhou, R. High-performance SSZ-13 membranes prepared using ball-milled nanosized seeds for carbon dioxide and nitrogen separations from methane. Chin. J. Chem. Eng. 2020, 28, 1285-1292. [CrossRef]

66. Tang, X.; Zhang, Y.; Meng, D.; Kong, X.; Kong, L.; Qiu, H.; Xu, N.; Guo, W.; Yang, S.; Zhang, Y. Efficient synthesis of thin SSZ-13 membranes by gel-less method. J. Membr. Sci. 2020, 620, 118920. [CrossRef]

67. Tang, X.; Zhang, Y.; Meng, D.; Kong, X.; Yang, S.; Guo, W.; Qiu, H.; Kong, L.; Zhang, Y.; Zhang, Z. Fast synthesis of thin SSZ-13 membranes by a hot-dipping method. J. Membr. Sci. 2021, 629, 119297. [CrossRef]

68. Wang, B.; Wang, Y.; Li, X.; Zhong, S.; Zhou, R. Highly $\mathrm{CO}_{2}$-selective and moisture-resistant bilayer silicalite-1/SSZ-13 membranes with gradient pores for wet $\mathrm{CO}_{2} / \mathrm{CH}_{4}$ and $\mathrm{CO}_{2} / \mathrm{N}_{2}$ separations. J. Membr. Sci. 2021, 636, 119565. [CrossRef]

69. Jang, E.; Hong, S.; Kim, E.; Choi, N.; Cho, S.J.; Choi, J. Organic template-free synthesis of high-quality CHA type zeolite membranes for carbon dioxide separation. J. Membr. Sci. 2018, 549, 46-59. [CrossRef]

70. Zhou, R.; Wang, H.; Wang, B.; Chen, X.; Li, S.; Yu, M. Defect-Patching of Zeolite Membranes by Surface Modification Using Siloxane Polymers for $\mathrm{CO}_{2}$ Separation. Ind. Eng. Chem. Res. 2015, 54, 7516-7523. [CrossRef]

71. Imasaka, S.; Itakura, M.; Yano, K.; Fujita, S.; Okada, M.; Hasegawa, Y.; Abe, C.; Araki, S.; Yamamoto, H. Rapid preparation of high-silica CHA-type zeolite membranes and their separation properties. Sep. Purif. Technol. 2018, 199, 298-303. [CrossRef]

72. Yang, S.; Chiang, Y.; Nair, S. Scalable One-Step Gel Conversion Route to High-Performance CHA Zeolite Hollow Fiber Membranes and Modules for $\mathrm{CO}_{2}$ Separation. Energy Technol. 2019, 7, 1900494. [CrossRef] 
73. Wu, T.; Diaz, M.C.; Zheng, Y.; Zhou, R.; Funke, H.H.; Falconer, J.L.; Noble, R.D. Influence of propane on $\mathrm{CO}_{2} / \mathrm{CH}_{4}$ and $\mathrm{N}_{2} / \mathrm{CH}_{4}$ separations in CHA zeolite membranes. J. Membr. Sci. 2015, 473, 201-209. [CrossRef]

74. Yu, L.; Holmgren, A.; Zhou, M.; Hedlund, J. Highly permeable CHA membranes prepared by fluoride synthesis for efficient $\mathrm{CO}_{2} / \mathrm{CH}_{4}$ separation. J. Mater. Chem. A 2018, 6, 6847-6853. [CrossRef]

75. Yu, L.; Holmgren, A.; Hedlund, J. A novel method for fabrication of high-flux zeolite membranes on supports with arbitrary geometry. J. Mater. Chem. A 2019, 7, 10325-10330. [CrossRef]

76. Lee, M.; Jeong, Y.; Hong, S.; Choi, J. High performance $\mathrm{CO}_{2}$-perm-selective SSZ-13 membranes: Elucidation of the link between membrane material and module properties. J. Membr. Sci. 2020, 611, 118390. [CrossRef]

77. Jeong, Y.; Lee, M.; Lee, G.; Hong, S.; Jang, E.; Choi, N.; Choi, J. Unavoidable but minimizable microdefects in a polycrystalline zeolite membrane: Its remarkable performance for wet $\mathrm{CO}_{2} / \mathrm{CH}_{4}$ separation. J. Mater. Chem. A 2021, 9, 12593-12605. [CrossRef]

78. Li, Y.; Wang, Y.; Guo, M.; Liu, B.; Zhou, R.; Lai, Z. High-performance 7-channel monolith supported SSZ-13 membranes for high-pressure $\mathrm{CO}_{2} / \mathrm{CH}_{4}$ separations. J. Membr. Sci. 2021, 629, 119277. [CrossRef]

79. Kida, K.; Maeta, Y.; Yogo, K. Preparation and gas permeation properties on pure silica CHA-type zeolite membranes. J. Membr. Sci. 2017, 522, 363-370. [CrossRef]

80. Liang, L.; Zhu, M.; Chen, L.; Zhong, C.; Yang, Y.; Wu, T.; Wang, H.; Kumakiri, I.; Chen, X.; Kita, H. Single Gas Permeance Performance of High Silica SSZ-13 Zeolite Membranes. Membranes 2018, 8, 43. [CrossRef]

81. Zhu, M.-H.; Liang, L.; Wang, H.; Liu, Y.; Wu, T.; Zhang, F.; Li, Y.; Kumakiri, I.; Chen, X.; Kita, H. Influences of Acid Post-Treatment on High Silica SSZ-13 Zeolite Membrane. Ind. Eng. Chem. Res. 2019, 58, 14037-14043. [CrossRef]

82. Araki, S.; Okubo, Y.; Maekawa, K.; Imasaka, S.; Yamamoto, H. Preparation of a high-silica chabazite-type zeolite membrane with high $\mathrm{CO}_{2}$ permeability using tetraethylammonium hydroxide. J. Membr. Sci. 2020, 613, 118480. [CrossRef]

83. Araki, S.; Yamashita, R.; Li, K.; Yamamoto, H. Preparation and gas permeation properties of all-silica CHA zeolite hollow fiber membranes prepared on amorphous-silica hollow fibers. J. Membr. Sci. 2021, 634, 119338. [CrossRef]

84. Meshkat, A.; Vaezi, M.J.; Babaluo, A.A.; Geranbaha, M.G. Parametric studies of DD3R particles seeding on the modified surface of $\alpha$-alumina support and synthesis of DD3R zeolite membrane. J. Eur. Ceram. Soc. 2018, 38, 5074-5081. [CrossRef]

85. Hayakawa, E.; Himeno, S. Synthesis of a DDR-type zeolite membrane by using dilute solutions of various alkali metal salts. Sep. Purif. Technol. 2019, 218, 89-96. [CrossRef]

86. Hayakawa, E.; Himeno, S. Synthesis and Characteristics of Al-containing ZSM-58 Zeolite Membrane for $\mathrm{CO}_{2}$ Separation. Int. J. Chem. Eng. Appl. 2020, 11, 6-13. [CrossRef]

87. Hayakawa, E.; Himeno, S. Synthesis of all-silica ZSM-58 zeolite membranes for separation of $\mathrm{CO}_{2} / \mathrm{CH}_{4}$ and $\mathrm{CO}_{2} / \mathrm{N}_{2}$ gas mixtures. Microporous Mesoporous Mater. 2019, 291, 109695. [CrossRef]

88. Hasegawa, H.; Nishida, K.; Oguro, S.; Fujimura, Y.; Yajima, K.; Niino, M.; Isomura, M.; Tomita, T. Gas separation process for $\mathrm{CO}_{2}$ removal from natural gas with DDR-type zeolite membrane. Energy Procedia 2017, 114, 32-36. [CrossRef]

89. Himeno, S.; Tomita, T.; Suzuki, K.; Nakayama, K.; Yajima, K.; Yoshida, S. Synthesis and Permeation Properties of a DDR-Type Zeolite Membrane for Separation of $\mathrm{CO}_{2} / \mathrm{CH}_{4}$ Gaseous Mixtures. Ind. Eng. Chem. Res. 2007, 46, 6989-6997. [CrossRef]

90. Okazaki, J.; Hasegawa, H.; Chikamatsu, N.; Yajima, K.; Shimizu, K.; Niino, M. DDR-type zeolite membrane: A novel CO 2 separation technology for enhanced oil recovery. Sep. Purif. Technol. 2019, 218, 200-205. [CrossRef]

91. Wang, M.; Bai, L.; Li, M.; Gao, L.; Wang, M.; Rao, P.; Zhang, Y. Ultrafast synthesis of thin all-silica DDR zeolite membranes by microwave heating. J. Membr. Sci. 2018, 572, 567-579. [CrossRef]

92. Vaezi, M.J.; Babaluo, A.A.; Maghsoudi, H. Synthesis, modification and gas permeation properties of DD3R zeolite membrane for separation of natural gas impurities $\left(\mathrm{N}_{2}\right.$ and $\left.\mathrm{CO}_{2}\right)$. J. Nat. Gas Sci. Eng. 2018, 52, 423-431. [CrossRef]

93. Xu, N.; Liu, Z.; Zhang, Y.; Qiu, H.; Kong, L.; Tang, X.; Meng, D.; Kong, X.; Wang, M.; Zhang, Y. Fast synthesis of thin all-silica DDR zeolite membranes by co-template strategy. Microporous Mesoporous Mater. 2020, 298, 110091. [CrossRef]

94. Xu, N.; Meng, D.; Tang, X.; Kong, X.; Kong, L.; Zhang, Y.; Qiu, H.; Wang, M.; Zhang, Y. Fast synthesis of thin all-silica DDR zeolite membranes with inorganic base as mineralizing agent for $\mathrm{CO}_{2}-\mathrm{CH}_{4}$ separation. Sep. Purif. Technol. 2020, 253, 117505. [CrossRef]

95. Nguyen, N.M.; Le, Q.T.; Nguyen, D.P.-H.; Nguyen, T.N.; Le, T.T.; Pham, T.C.-T. Facile synthesis of seed crystals and gelless growth of pure silica DDR zeolite membrane on low cost silica support for high performance in $\mathrm{CO}_{2}$ separation. J. Membr. Sci. 2021, 624, 119110. [CrossRef]

96. Du, P.; Song, J.; Wang, X.; Zhang, Y.; Xie, J.; Liu, G.; Liu, Y.; Wang, Z.; Hong, Z.; Gu, X. Efficient scale-up synthesis and hydrogen separation of hollow fiber DD3R zeolite membranes. J. Membr. Sci. 2021, 636, 119546. [CrossRef]

97. Yang, S.; Cao, Z.; Arvanitis, A.; Sun, X.; Xu, Z.; Dong, J. DDR-type zeolite membrane synthesis, modification and gas permeation studies. J. Membr. Sci. 2016, 505, 194-204. [CrossRef]

98. Tomita, T.; Nakayama, K.; Sakai, H. Gas separation characteristics of DDR type zeolite membrane. Microporous Mesoporous Mater 2004, 68, 71-75. [CrossRef]

99. Jeong, Y.; Hong, S.; Jang, E.; Kim, E.; Baik, H.; Choi, N.; Yip, A.C.K.; Choi, J. An Hetero-Epitaxially Grown Zeolite Membrane. Angew. Chem. Int. Ed. 2019, 58, 18654-18662. [CrossRef]

100. Zhang, Y.; Chen, S.; Shi, R.; Du, P.; Qiu, X.; Gu, X. Pervaporation dehydration of acetic acid through hollow fiber supported DD3R zeolite membrane. Sep. Purif. Technol. 2018, 204, 234-242. [CrossRef]

101. Sen, M.; Dana, K.; Das, N. Development of LTA zeolite membrane from clay by sonication assisted method at room temperature for $\mathrm{H} 2-\mathrm{CO} 2$ and CO2-CH4 separation. Ultrason. Sonochemistry 2018, 48, 299-310. [CrossRef] 
102. Carreon, M.L.; Li, S.; Carreon, M.A. AlPO-18 membranes for $\mathrm{CO}_{2} / \mathrm{CH}_{4}$ separation. Chem. Commun. 2012, 48, $2310-2312$. [CrossRef]

103. Zhan, T.; Wu, T.; Shi, Y.; Chen, X.; Li, Y.; Zhu, M.; Zhang, F.; Kumakiri, I.; Chen, X.; Kita, H. Influence of synthesis parameters on preparation of AlPO-18 membranes by single DIPEA for $\mathrm{CO}_{2} / \mathrm{CH}_{4}$ separation. J. Membr. Sci. 2020, 601, 117853. [CrossRef]

104. Wu, T.; Tanaka, K.; Chen, X.; Kumakiri, I.; Kita, H. Synthesis and Gas Permeation Properties of AEI Zeolite Membranes by DIPEA as a Template. Membrane 2018, 43, 67-73. [CrossRef]

105. Liu, B.; Kumakiri, I.; Tanaka, K.; Chen, X.; Kita, H. Preparation of Rho Zeolite Membranes on Tubular Supports. Membrane 2016, 41, 81-86. [CrossRef]

106. Zhong, S.; Bu, N.; Zhou, R.; Jin, W.; Yu, M.; Li, S. Aluminophosphate-17 and silicoaluminophosphate- 17 membranes for $\mathrm{CO}_{2}$ separations. J. Membr. Sci. 2016, 520, 507-514. [CrossRef]

107. Chew, T.L.; Yeong, Y.F.; Ho, C.D.; Ahmad, A.L. Ion-Exchanged Silicoaluminophosphate- 34 Membrane for Efficient $\mathrm{CO}_{2} / \mathrm{N}_{2}$ Separation with Low $\mathrm{CO}_{2}$ Concentration in the Gas Mixture. Ind. Eng. Chem. Res. 2018, 58, 729-735. [CrossRef]

108. Makertihartha, I.; Kencana, K.S.; Dwiputra, T.R.; Khoiruddin, K.; Mukti, R.R.; Wenten, I. Silica supported SAPO-34 membranes for CO2/N2 separation. Microporous Mesoporous Mater. 2020, 298, 110068. [CrossRef]

109. Liu, B.; Tang, C.; Li, X.; Wang, B.; Zhou, R. High-performance SAPO-34 membranes for CO2 separations from simulated flue gas Microporous Mesoporous Mater. 2019, 292, 109712. [CrossRef]

110. Kgaphola, K.; Sigalas, I.; Daramola, M.O. Synthesis and characterization of nanocomposite SAPO-34/ceramic membrane for post-combustion $\mathrm{CO}_{2}$ capture. Asia-Pac. J. Chem. Eng. 2017, 12, 894-904. [CrossRef]

111. Kim, E.; Lee, T.; Kim, H.; Jung, W.-J.; Han, D.-Y.; Baik, H.; Choi, N.; Choi, J. Chemical Vapor Deposition on Chabazite (CHA) Zeolite Membranes for Effective Post-Combustion CO2 Capture. Environ. Sci. Technol. 2014, 48, 14828-14836. [CrossRef]

112. Zito, P.F.; Brunetti, A.; Drioli, E.; Barbieri, G. CO2 Separation via a DDR Membrane: Mutual Influence of Mixed Gas Permeation. Ind. Eng. Chem. Res. 2019, 59, 7054-7060. [CrossRef]

113. Merkel, T.C.; Zhou, M.; Baker, R.W. Carbon dioxide capture with membranes at an IGCC power plant. J. Membr. Sci. 2012, 389, 441-450. [CrossRef]

114. Hu, L.; Pal, S.; Nguyen, H.; Bui, V.; Lin, H. Molecularly engineering polymeric membranes for $\mathrm{H}_{2} / \mathrm{CO}_{2}$ separation at $100-300{ }^{\circ} \mathrm{C}$. J. Appl. Polym. Sci. 2020, 58, 2467-2481. [CrossRef]

115. Huang, A.; Liu, Q.; Wang, N.; Tong, X.; Huang, B.; Wang, M.; Caro, J. Covalent synthesis of dense zeolite LTA membranes on various 3-chloropropyltrimethoxysilane functionalized supports. J. Membr. Sci. 2013, 437, 57-64. [CrossRef]

116. Huang, A.; Wang, N.; Caro, J. Synthesis of multi-layer zeolite LTA membranes with enhanced gas separation performance by using 3-aminopropyltriethoxysilane as interlayer. Microporous Mesoporous Mater. 2012, 164, 294-301. [CrossRef]

117. Zheng, Z.; Hall, A.S.; Guliants, V.V. Synthesis, characterization and modification of DDR membranes grown on $\alpha$-alumina supports. J. Mater. Sci. 2008, 43, 2499-2502. [CrossRef]

118. Kanezashi, M.; O’Brien-Abraham, J.; Lin, Y.S.; Suzuki, K. Gas permeation through DDR-type zeolite membranes at high temperatures. AIChE J. 2008, 54, 1478-1486. [CrossRef]

119. Bose, A.; Das, N.; Roy, S.N.; Goswami, N.; Kar, S.; Bindal, R.; Tewari, P.K. Synthesis, characterization and corrosion performance evaluation of DDR membrane for $\mathrm{H} 2$ separation from HI decomposition reaction. Int. J. Hydrogen Energy 2014, 39, 12795-12803. [CrossRef]

120. Zhou, L.; Yang, J.; Li, G.; Wang, J.; Zhang, Y.; Lu, J.; Yin, D. Highly $\mathrm{H}_{2}$ permeable SAPO-34 membranes by steam-assisted conversion seeding. Int. J. Hydrogen Energy 2014, 39, 14949-14954. [CrossRef]

121. Bose, A.; Sen, M.; Das, J.K.; Das, N. Sonication mediated hydrothermal process-An efficient method for the rapid synthesis of DDR zeolite membranes. RSC Adv. 2014, 4, 19043-19052. [CrossRef]

122. Huang, A.; Liang, F.; Steinbach, F.; Caro, J. Preparation and separation properties of LTA membranes by using 3aminopropyltriethoxysilane as covalent linker. J. Membr. Sci. 2010, 350, 5-9. [CrossRef]

123. Wei, X.-L.; Liang, S.; Xu, Y.-Y.; Sun, Y.-L.; An, J.-F.; Chao, Z.-S. Patching NaA zeolite membrane by adding methylcellulose into the synthesis gel. J. Membr. Sci. 2017, 530, 240-249. [CrossRef]

124. Yu, L.; Nobandegani, M.; Hedlund, J. High performance fluoride MFI membranes for efficient $\mathrm{CO}_{2} / \mathrm{H}_{2}$ separation. J. Membr. Sci. 2020, 616, 118623. [CrossRef]

125. Liu, B.; Zhang, R.; Du, Y.; Gao, F.; Zhou, J.; Zhou, R. Highly selective high-silica SSZ-13 zeolite membranes for $\mathrm{H}_{2}$ production from syngas. Int. J. Hydrogen Energy 2020, 45, 16210-16218. [CrossRef]

126. Abe, J.O.; Popoola, A.P.I.; Ajenifuja, E.; Popoola, O.M. Hydrogen energy, economy and storage: Review and recommendation. Int. J. Hydrogen Energy 2019, 44, 15072-15086. [CrossRef]

127. Sinha, V.; Govindarajan, N.; De Bruin, B.; Meijer, E.J. How Solvent Affects C-H Activation and Hydrogen Production Pathways in Homogeneous Ru-Catalyzed Methanol Dehydrogenation Reactions. ACS Catal. 2018, 8, 6908-6913. [CrossRef]

128. Van Acht, S.; Laycock, C.; Carr, S.; Maddy, J.; Guwy, A.; Lloyd, G.; Raymakers, L.; Wright, A. Optimization of VPSA-EHP/C process for high-pressure hydrogen recovery from Coke Oven Gas using CO selective adsorbent. Int. J. Hydrogen Energy 2020, 46, 709-725. [CrossRef]

129. Dong, Q.; Jiang, J.; Li, S.; Yu, M. Molecular layer deposition (MLD) modified SSZ-13 membrane for greatly enhanced $\mathrm{H}_{2}$ separation. J. Membr. Sci. 2021, 622, 119040. [CrossRef] 
130. Mei, W.; Du, Y.; Wu, T.; Gao, F.; Wang, B.; Duan, J.; Zhou, J.; Zhou, R. High-flux CHA zeolite membranes for $\mathrm{H}_{2}$ separations. J. Membr. Sci. 2018, 565, 358-369. [CrossRef]

131. Wu, T.; Shu, C.; Liu, S.; Xu, B.; Zhong, S.; Zhou, R. Separation Performance of Si-CHA Zeolite Membrane for a Binary $\mathrm{H}_{2} / \mathrm{CH}_{4}$ Mixture and Ternary and Quaternary Mixtures Containing Impurities. Energy Fuels 2020, 34, 11650-11659. [CrossRef]

132. Huang, A.; Caro, J. Steam-stable hydrophobic ITQ-29 molecular sieve membrane with $\mathrm{H}_{2}$ selectivity prepared by secondary growth using Kryptofix 222 as SDA. Chem. Commun. 2010, 46, 7748-7750. [CrossRef] [PubMed]

133. Baker, R.W.; Lokhandwala, K. Natural Gas Processing with Membranes: An Overview. Ind. Eng. Chem. Res. 2008, 47, $2109-2121$. [CrossRef]

134. Li, Y.; He, S.; Shu, C.; Li, X.; Liu, B.; Zhou, R.; Lai, Z. A facile approach to synthesize SSZ-13 membranes with ultrahigh $\mathrm{N}_{2}$ permeances for efficient $\mathrm{N}_{2} / \mathrm{CH}_{4}$ separations. J. Membr. Sci. 2021, 632, 119349. [CrossRef]

135. Zong, Z.; Carreon, M.A. Thin SAPO-34 membranes synthesized in stainless steel autoclaves for N2/CH4 separation. J. Membr. Sci. 2017, 524, 117-123. [CrossRef]

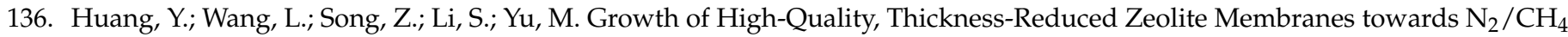
Separation Using High-Aspect-Ratio Seeds. Angew. Chem. Int. Ed. 2015, 54, 10843-10847. [CrossRef]

137. Alam, S.F.; Kim, M.-Z.; Kim, Y.J.; Rehman, A.U.; Devipriyanka, A.; Sharma, P.; Yeo, J.-G.; Lee, J.-S.; Kim, H.; Cho, C.-H. A new seeding method, dry rolling applied to synthesize SAPO-34 zeolite membrane for nitrogen/methane separation. J. Membr. Sci. 2020, 602, 117825. [CrossRef]

138. Zong, Z.; Feng, X.; Huang, Y.; Song, Z.; Zhou, R.; Zhou, S.J.; Carreon, M.A.; Yu, M.; Li, S. Highly permeable $\mathrm{N}_{2} / \mathrm{CH}_{4}$ separation SAPO-34 membranes synthesized by diluted gels and increased crystallization temperature. Microporous Mesoporous Mater. 2016, 224, 36-42. [CrossRef]

139. Li, S.; Zong, Z.; Zhou, S.J.; Huang, Y.; Song, Z.; Feng, X.; Zhou, R.; Meyer, H.S.; Yu, M.; Carreon, M.A. SAPO-34 Membranes for $\mathrm{N}_{2} / \mathrm{CH}_{4}$ separation: Preparation, characterization, separation performance and economic evaluation. J. Membr. Sci. 2015, 487, 141-151. [CrossRef]

140. Tiscornia, I.; Valencia, S.; Corma, A.; Téllez, C.; Coronas, J.; Santamaría, J. Preparation of ITQ-29 (Al-free zeolite A) membranes. Microporous Mesoporous Mater. 2008, 110, 303-309. [CrossRef]

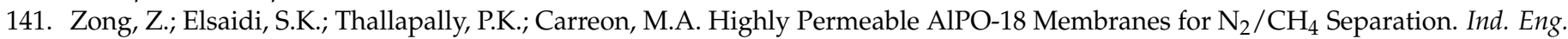
Chem. Res. 2017, 56, 4113-4118. [CrossRef]

142. Xu, X.; Yang, W.; Liu, J.; Lin, L. Synthesis and perfection evaluation of NaA zeolite membrane. Sep. Purif. Technol. 2001, 25, 475-485. [CrossRef]

143. Wang, H.; Huang, L.; Holmberg, B.A.; Yan, Y. Nanostructured zeolite 4A molecular sieving air separation membranes. Chem. Commun. 2002, 1708-1709. [CrossRef]

144. Feng, X.; Zong, Z.; Elsaidi, S.K.; Jasinski, J.B.; Krishna, R.; Thallapally, P.K.; Carreon, M.A. Kr/Xe Separation over a Chabazite Zeolite Membrane. J. Am. Chem. Soc. 2016, 138, 9791-9794. [CrossRef]

145. Kwon, Y.H.; Kiang, C.; Benjamin, E.; Crawford, P.; Nair, S.; Bhave, R. Krypton-xenon separation properties of SAPO-34 zeolite materials and membranes. AIChE J. 2016, 63, 761-769. [CrossRef]

146. Wu, T.; Lucero, J.; Zong, Z.; Elsaidi, S.K.; Thallapally, P.K.; Carreon, M.A. Microporous Crystalline Membranes for Kr/Xe Separation: Comparison Between AlPO-18, SAPO-34, and ZIF-8. ACS Appl. Nano Mater. 2017, 1, 463-470. [CrossRef]

147. Wu, T.; Feng, X.; Elsaidi, S.K.; Thallapally, P.K.; Carreon, M.A. Zeolitic Imidazolate Framework-8 (ZIF-8) Membranes for Kr/Xe Separation. Ind. Eng. Chem. Res. 2017, 56, 1682-1686. [CrossRef]

148. Wang, X.; Zhou, T.; Zhang, P.; Yan, W.; Li, Y.; Peng, L.; Veerman, D.; Shi, M.; Gu, X.; Kapteijn, F. High-Silica CHA Zeolite Membrane with Ultra-High Selectivity and Irradiation Stability for Krypton/Xenon Separation. Angew. Chem. Int. Ed. 2021, 60, 9032-9037. [CrossRef] [PubMed]

149. Wang, X.; Zhang, Y.; Wang, X.; Andres-Garcia, E.; Du, P.; Giordano, L.; Wang, L.; Hong, Z.; Gu, X.; Murad, S.; et al. Xenon Recovery by DD3R Zeolite Membranes: Application in Anaesthetics. Angew. Chem. Int. Ed. 2019, 58, 15518-15525. [CrossRef]

150. Shirazian, S.; Ashrafizadeh, S.N. LTA and ion-exchanged LTA zeolite membranes for dehydration of natural gas. J. Ind. Eng. Chem. 2015, 22, 132-137. [CrossRef]

151. Aoki, K.; Kusakabe, A.K.; Morooka, S. Separation of Gases with an A-Type Zeolite Membrane. Ind. Eng. Chem. Res. 2000, 39, 2245-2251. [CrossRef]

152. Li, H.; Qiu, C.; Ren, S.; Dong, Q.; Zhang, S.; Zhou, F.; Liang, X.; Wang, J.; Li, S.; Yu, M. Na + -gated water-conducting nanochannels for boosting $\mathrm{CO}_{2}$ conversion to liquid fuels. Science 2020, 367, 667-671. [CrossRef] [PubMed]

153. Inami, H.; Abe, C.; Hasegawa, Y. Development of Ammonia Selectively Permeable Zeolite Membrane for Sensor in Sewer System. Membranes 2021, 11, 348. [CrossRef] [PubMed]

154. Díaz-Cabañas, M.-J.; Barrett, P.A. Synthesis and structure of pure $\mathrm{SiO}_{2}$ chabazite: $\mathrm{The}^{\mathrm{SiO}} 2$ polymorph with the lowest framework density. Chem. Commun. 1998, 1881-1882. [CrossRef]

155. Hasegawa, Y.; Hotta, H.; Sato, K.; Nagase, T.; Mizukami, F. Preparation of novel chabazite (CHA)-type zeolite layer on porous

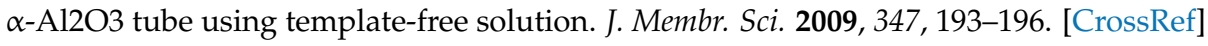

156. Liu, B.; Zheng, Y.; Hu, N.; Gui, T.; Li, Y.; Zhang, F.; Zhou, R.; Chen, X.; Kita, H. Synthesis of low-silica CHA zeolite chabazite in fluoride media without organic structural directing agents and zeolites. Microporous Mesoporous Mater. 2014, 196, 270-276. [CrossRef] 
157. Den Exter, M.J.; Jansen, J.C.; van Bekkum, H. Separation of Permanent Gases on the All-Silica 8-Ring Clathrasil DD3R. Stud. Surf. Sci. Catal. 1994, 84, 1159-1166. [CrossRef]

158. Yang, S.; Provenzano, J.; Arvanitis, A.; Jing, W.; Dong, J.; Arvanitis, A. Morphological control of DDR zeolite crystals in Sigma-1 assisted hydrothermal synthesis using reduced organic agents. J. Porous Mater. 2014, 21, 1001-1007. [CrossRef]

159. Li, Y.; Yang, W. Microwave synthesis of zeolite membranes: A review. J. Membr. Sci. 2008, 316, 3-17. [CrossRef]

160. Morigami, Y.; Kondo, M.; Abe, J.; Kita, H.; Okamoto, K. The first large-scale pervaporation plant using tubular-type module with zeolite NaA membrane. Sep. Purif. Technol. 2001, 25, 251-260. [CrossRef]

161. Okamoto, K.-I.; Kita, H.; Horii, A.K.; Kondo, K.T. Zeolite NaA Membrane: Preparation, Single-Gas Permeation, and Pervaporation and Vapor Permeation of Water/Organic Liquid Mixtures. Ind. Eng. Chem. Res. 2000, 40, 163-175. [CrossRef]

162. Yin, X.; Zhu, G.S.; Yang, W.; Li, Y.; Zhu, G.Q.; Sun, J.; Qiu, S.; Xu, R.; Xu, R.R. Stainless-Steel-Net-Supported Zeolite NaA Membrane with High Permeance and High Permselectivity of Oxygen over Nitrogen. Adv. Mater. 2005, 17, 2006-2010. [CrossRef]

163. Li, Y.; Chen, H.; Liu, J.; Yang, W. Microwave synthesis of LTA zeolite membranes without seeding. J. Membr. Sci. 2006, 277, 230-239. [CrossRef]

164. Xu, K.; Yuan, C.; Caro, J.; Huang, A. Silver-exchanged zeolite LTA molecular sieving membranes with enhanced hydrogen selectivity. J. Membr. Sci. 2016, 511, 1-8. [CrossRef]

165. Anbia, M.; Mousavi, A.A.; Sepehrian, M. Synthesis and Characterization of a Novel Modified ANA Zeolite Membrane. J. Ultrafine Grained Nanostructured Mater. 2019, 52, 90-97. [CrossRef]

166. Dong, J.; Lin, Y.S. In Situ Synthesis of P-Type Zeolite Membranes on Porous $\alpha$-Alumina Supports. Ind. Eng. Chem. Res. 1998, 37, 2404-2409. [CrossRef] 